\title{
Effects of Soil Water Deficit at Different Growth Stages on Maize Growth, Yield, and Water Use Efficiency under Alternate Partial Root-Zone Irrigation
}

\author{
Minghui Cheng ${ }^{1}$, Haidong Wang ${ }^{1, *}$, Junliang Fan ${ }^{1, *}$, Fucang Zhang ${ }^{1, *}$ and Xiukang Wang ${ }^{1,2}$ \\ 1 Key Laboratory of Agricultural Soil and Water Engineering in Arid and Semiarid Areas of the Ministry \\ of Education, Northwest A\&F University, Yangling 712100, China; Chengmhui@nwafu.edu.cn (M.C.); \\ wangxiukang@yau.edu.cn (X.W.) \\ 2 College of Life Science, Yan'an University, Yan'an 716000, China \\ * Correspondence: wanghd@nwsuaf.edu.cn (H.W.); nwwfjl@gmail.com (J.F.); zhangfc@nwsuaf.edu.cn (F.Z.)
}

Citation: Cheng, M.; Wang, H.; Fan, J.; Zhang, F.; Wang, X. Effects of Soil Water Deficit at Different Growth Stages on Maize Growth, Yield, and Water Use Efficiency under Alternate Partial Root-Zone Irrigation. Water 2021, 13, 148. https://doi.org/ 10.3390/w13020148

Received: 13 November 2020

Accepted: 6 January 2021

Published: 10 January 2021

Publisher's Note: MDPI stays neutral with regard to jurisdictional clai$\mathrm{ms}$ in published maps and institutional affiliations.

Copyright: (C) 2021 by the authors. Licensee MDPI, Basel, Switzerland. This article is an open access article distributed under the terms and conditions of the Creative Commons Attribution (CC BY) license (https:// creativecommons.org/licenses/by/ $4.0 /)$.

\begin{abstract}
To investigate the effects of alternate partial root-zone irrigation (APRI) and water deficit at different growth stages on maize growth, physiological characteristics, the grain yield, and the water use efficiency (WUE), a pot experiment was conducted under a mobile automatic rain shelter. There were two irrigation methods, i.e., conventional irrigation (CI) and APRI; two irrigation levels, i.e., mild deficit irrigation ( $\mathrm{W}_{1}, 55 \% \sim 70 \% \mathrm{FC}$, where $\mathrm{FC}$ is the field capacity) and serious deficit irrigation $\left(\mathrm{W}_{2}, 40 \% \sim 55 \% \mathrm{FC}\right)$; and two deficit stages, i.e., the seedling (S) and milking stage (M). Sufficient irrigation $\left(\mathrm{W}_{0}: 70 \% \sim 85 \% \mathrm{FC}\right)$ was applied throughout the growing season of maize as the control treatment $(\mathrm{CK})$. The results indicated that APRI and CI decreased the total water consumption (ET) by $34.7 \%$ and $23.8 \%$ compared to $C K$, respectively. In comparison to CK, APRI and CI increased the yield-based water use efficiency (WUEY) by $41 \%$ and $7.7 \%$, respectively. APRI increased the

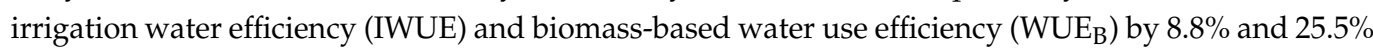
compared to $\mathrm{CK}$, respectively. Additionally, $\mathrm{ASW}_{1}$ had a similar grain yield to $\mathrm{CK}$ and the largest harvest index (HI). However, the chlorophyll and carotenoid contents were significantly reduced by $13.7 \%$ and $23.1 \%$ under $C I$, and by $11.3 \%$ and $20.3 \%$ under APRI, compared to CK, respectively. Deficit irrigation at the milking stage produced a longer tip length, resulting in a lower grain yield. Based on the entropy weight method and the technique for order preference by similarity to an ideal solution (TOPSIS) method, multi-objective optimization was obtained when mild deficit irrigation (55\% 70\% FC) occurred at the seedling stage under APRI.
\end{abstract}

Keywords: irrigation method; deficit stage; irrigation level; grain yield; water use efficiency; maize

\section{Introduction}

In light of the current pressure on increasing crop production, establishing a highyield and water-saving agricultural water use strategy to achieve highly efficient agricultural water use has become a priority for the sustainable development of agriculture in China [1-4]. According to the needs of various plants and their growth conditions, accurate estimation of the water demand and the use of irrigation schedules will improve the water use efficiency (WUE) [5]. Deficit irrigation and partial root-zone irrigation (PRI) are potentially water-saving irrigation strategies. PRI includes alternate partial root-zone irrigation (APRI) and fixed partial root-zone irrigation (FPRI) [6]. It can make the horizontal or vertical soil profile in the root layer either dry or wet. WUE can be increased without sacrificing the amount of photosynthate by regulating the function of plant stomata and the root system in response to drought stress [7].

Over the past few decades, the potential of APRI in saving water and improving WUE has been well-examined in many crops [8-12]. Liang et al. [13] demonstrated that APRI saved $29.1 \%$ of water and WUE was increased by $24.3 \%$ under the conditions of fertilization 
and full irrigation compared with conventional irrigation. Kang et al. [14] found that, when the irrigation amount was reduced by $50 \%$, the grain yield of conventional furrow irrigation and fixed furrow irrigation exhibited a downward trend, while the alternate furrow irrigation still retained a high grain yield. In addition, APRI not only significantly increased WUE, but also enhanced the activity of soil mineral nitrogen, which was in favor of crops on soil nitrogen uptake and utilization [15-17]. In short, the application of APRI can not only save irrigation water and maintain the crop yield, but also adjust the growth and physiological characteristics of crops.

It is generally believed that water deficit markedly inhibits maize growth, expansion of the leaf area, and the efficiency of photosystem II (quantum grain), but the plant height and leaf area can be compensated for to a large extent after re-watering [18-20]. However, some researchers found that appropriate moisture regulation increased the WUE of maize and increased its ability to resist drought [21-24]. Kebede et al. [25] found that reducing soil moisture to $75 \%$ in the field at the silking stage of maize did not markedly decrease the grain yield relative to full irrigation and saved a significant amount of water. Some researchers have also studied the impacts of water deficit at different growth stages on maize. Kang et al. [26] and Wei et al. [27] found that moderate water deficit at the seedling stage combined with mild water deficit at the jointing stage was beneficial to improvement of the grain yield and WUE. Liu et al. [28] pointed out that the compensation effect on the physiological and biochemical indexes after re-watering was better under water deficit at the seedling stage, followed by water deficit at the jointing stage. It can save irrigation water and regulate the growth and physiology of crops by ensuring an appropriate water deficit at different growth stages of crops.

However, previous studies have mainly focused on the impacts of partial root-zone irrigation or deficit irrigation at different crop growth stages and the combination of partial root-zone irrigation and fertilizer application on crop growth [29-32]. There are few studies on the combination of temporal water deficit at different crop growth stages and the spatial water deficit caused by APRI. The technique for order preference by similarity to an ideal solution (TOPSIS) method was first proposed by Hwang and Yoon in 1981 [33]. The method is a common and effective method in multi-objective decision-making analysis, which has been widely used over the past few decades [34]. It is a method of ranking according to the close degree between the limited evaluation objects and the ideal objectives, and is used to evaluate the relative advantages and disadvantages of the existing objects [35]. In this study, we aimed to investigate the responses of water stress-induced physiology, growth, and grain yield to two irrigation levels at different growth stages of maize through a pot experiment under APRI. Additionally, an optimal combination of the irrigation method, irrigation level, and deficit stage that can comprehensively improve the yield and water use efficiency was further proposed based on the TOPSIS method.

\section{Materials and Methods}

\subsection{Experimental Site}

A pot experiment was conducted in 2017 under a mobile automatic rain shelter at the Institute of Water-Saving Agriculture in Arid Areas of China, Northwest A\&F University $\left(108^{\circ} 04^{\prime} \mathrm{E}, 34^{\circ} 20^{\prime} \mathrm{N}\right.$, altitude $\left.521 \mathrm{~m}\right)$, Yangling, Shaanxi Province, China. This region belongs to the East Asian warm temperate semi-humid and semi-arid climate zone. The long-term annual precipitation is $505 \mathrm{~mm}$ and the average annual temperature is $12.5^{\circ} \mathrm{C}$. The study area has 210 frost-free days and a $2163.8 \mathrm{~h}$ sunshine duration. The tested soil was taken from a $0 \sim 20 \mathrm{~cm}$ soil layer of the local farmland. The main physical and chemical properties of the experimental soil before filling the pots were analyzed and are given in Table 1 . The daily air temperatures during the maize growing season are shown in Figure 1. 
Table 1. Physical and chemical properties of the experimental soil.

\begin{tabular}{|c|c|c|c|c|c|c|c|c|}
\hline $\begin{array}{c}\text { Soil } \\
\text { Texture }\end{array}$ & $\mathrm{pH}$ & $\begin{array}{c}\text { Field } \\
\text { Capacity } \\
(\mathrm{FC}, \%)\end{array}$ & $\begin{array}{c}\text { Wilting } \\
\text { Coefficient } \\
(\%)\end{array}$ & $\begin{array}{c}\text { Organic } \\
\text { Matter } \\
\text { (g/kg) }\end{array}$ & $\begin{array}{c}\text { Available } \\
\text { Potassium } \\
\text { (mg/kg) }\end{array}$ & $\begin{array}{c}\text { Ammonium } \\
\text { Nitrogen } \\
\text { (mg/kg) }\end{array}$ & $\begin{array}{c}\text { Nitrate } \\
\text { Nitrogen } \\
\text { (mg/kg) }\end{array}$ & $\begin{array}{c}\text { Available } \\
\text { Phosphorus } \\
\text { (mg/kg) }\end{array}$ \\
\hline $\begin{array}{l}\text { Heavy } \\
\text { loam }\end{array}$ & 8.1 & 24 & 8.5 & 12.0 & 13.13 & 7.70 & 21.8 & 6.5 \\
\hline
\end{tabular}

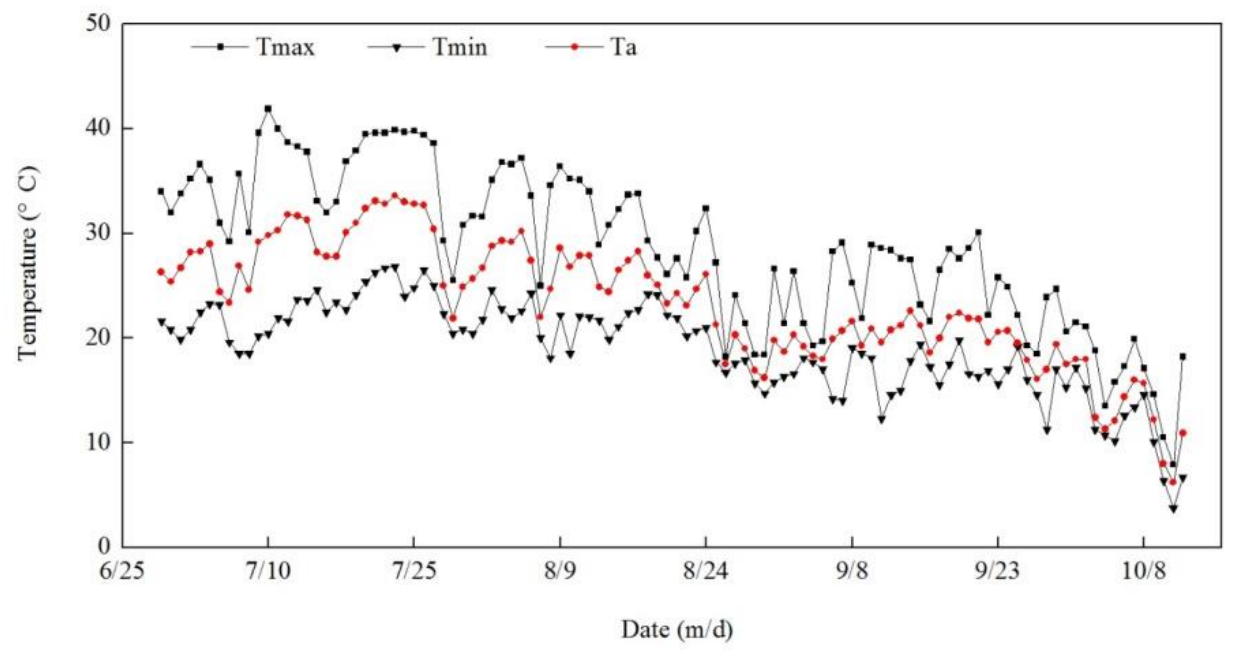

Figure 1. Daily air temperatures $\left(T_{\max }=\right.$ maximum air temperature, $T_{\min }=$ minimum air temperature, and $\mathrm{T}_{\mathrm{a}}=$ average air temperature) during the maize growing season in 2017.

\subsection{Experimental Design}

Pot experiments with two irrigation methods, two irrigation levels, and two deficit stages were conducted in 2017. The two irrigation methods were APRI (alternately watering in the two parts) and conventional irrigation (CI, evenly watering). The two irrigation levels included mild deficit irrigation ( $\mathrm{W}_{1}, 55 \% \sim 70 \%$ field capacity $\left.(\mathrm{FC})\right)$ and serious deficit irrigation $\left(\mathrm{W}_{2}, 40 \% \sim 55 \% \mathrm{FC}\right)$. The two deficit stages were the seedling stage (S) and milking stage $(\mathrm{M})$ of maize. Moreover, sufficient irrigation $\left(\mathrm{W}_{0}: 70 \% \sim 85 \% \mathrm{FC}\right)$ was applied throughout the growing season of maize as the control treatment (CK). The nine treatments were conducted with seven replicates, resulting in a total of 63 pots. The experimental details are shown in Table 2.

Table 2. Treatments of the experimental design.

\begin{tabular}{cccc}
\hline Irrigation Method & Deficit Stage & Irrigation Level & Code \\
\hline APRI & $\mathrm{S}$ & $\mathrm{W}_{1}$ & $\mathrm{ASW}_{1}$ \\
APRI & $\mathrm{S}$ & $\mathrm{W}_{2}$ & $\mathrm{ASW}_{2}$ \\
APRI & $\mathrm{M}$ & $\mathrm{W}_{1}$ & $\mathrm{AMW}_{1}$ \\
APRI & $\mathrm{W}$ & $\mathrm{W}_{2}$ & $\mathrm{AMW}_{2}$ \\
\hline CI & $\mathrm{S}$ & $\mathrm{W}_{1}$ & $\mathrm{CSW}_{1}$ \\
CI & $\mathrm{S}$ & $\mathrm{W}_{2}$ & $\mathrm{CSW}_{2}$ \\
CI & $\mathrm{W}$ & $\mathrm{W}_{1}$ & $\mathrm{CMW}_{1}$ \\
CI & $\mathrm{C}$ & $\mathrm{W}_{2}$ & $\mathrm{CMW}_{2}$ \\
\hline CI & $\mathrm{All}$ & $\mathrm{W}_{0}$ & $\mathrm{CW}_{0}$ \\
\hline
\end{tabular}

Note: APRI, alternate partial root-zone irrigation; $\mathrm{CI}$, conventional irrigation; $\mathrm{S}$, deficit irrigation during the seedling stage; $\mathrm{M}$, deficit irrigation during the milking stage; All, no deficit irrigation; $\mathrm{W}_{1}$, mild deficit irrigation ( $55 \% \sim 70 \%$ FC, where FC is the field capacity); $\mathrm{W}_{2}$, serious deficit irrigation ( $\left.40 \% \sim 55 \% \mathrm{FC}\right)$; and $\mathrm{W}_{0}$, sufficient irrigation $(70 \% \sim 85 \% \mathrm{FC})$. The same symbols were used for the following figures and tables.

The maize cultivar "Zheng Dan 958" (widely used locally) was sown in a constant temperature incubator at $28^{\circ} \mathrm{C}$. When the root number of maize seedlings was four, they 
were transplanted into plastic barrels on 29 June 2017. The barrel was made of polyethylene, with a volume of $50 \mathrm{~L}$, an upper width of $34 \mathrm{~cm}$, a bottom width of $29 \mathrm{~cm}$, and a height of $50 \mathrm{~cm}$. Each barrel was filled with $66 \mathrm{~kg}$ of soil with the bulk density of $1.35 \times 10^{3} \mathrm{~kg} \mathrm{~m}^{-3}$. The soil was naturally air-dried and sieved through a $2 \mathrm{~mm}$ sieve. An aluminum plate was installed in the center of the barrel to divide it into two equal portions under APRI, minimizing horizontal water exchange between the two parts of each barrel. The center of the upper part of the aluminum plate was opened with a " $\mathrm{V}$ " notch for transplanting maize. The roots were evenly distributed on two sides of the barrel, ensuring the same root amount in each part of the APRI treatment. Additionally, a PVC tube was installed in each part of the barrel to monitor the soil moisture content. To ensure ventilation and water permeability, eight holes ( $2 \mathrm{~cm}$ in diameter) were uniformly punched at the bottom of each barrel. In addition, a gauze and a 1-cm-thick sand layer were laid at the bottom. According to the local fertilization rate, total fertilizer $\left(0.2 \mathrm{~g} \mathrm{~N}, 0.15 \mathrm{~g} \mathrm{P}_{2} \mathrm{O}_{5}\right.$, and $0.1 \mathrm{~g} \mathrm{~K}_{2} \mathrm{O}$ soil) was fully mixed with the $10 \mathrm{~cm}$ surface soil as basal fertilizer in each barrel. Nitrogen, phosphorus, and potassium were further supplied as urea ( $\mathrm{N} 46 \%)$, superphosphate $\left(\mathrm{P}_{2} \mathrm{O}_{5}\right)$, and potassium Sulfide $\left(\mathrm{K}_{2} \mathrm{O}\right)$, respectively. Maize was harvested on 12 October.

After transplantation, the soil moisture content in all barrels was controlled at $55 \%$ FC. When maize entered the four-leaf stage, all barrels started to control the soil moisture content. When the average soil moisture content in the barrel dropped to or close to the lower irrigation limit $( \pm 5 \%)$, irrigation was carried out with tap water and irrigated to the upper limit. The alternation of irrigation occurred under APRI when the average soil water content on the dry side declined to or close to the irrigation limit $( \pm 5 \%)$ (Figure 2). During deficit irrigation, the soil moisture content was controlled at $W_{1}$ or $W_{2}$, while maize was irrigated according to $\mathrm{W}_{0}$ at other stages. The irrigation amount was determined by the weighing method and the weighting interval was every day or every two days, according to crop growth and weather conditions. Each irrigation was performed in the afternoon. The irrigation schedule during the maize growing season is shown in Figure 3. The crop water consumption $\left(E T, \mathrm{~kg} \mathrm{plant}^{-1}\right)$ and irrigation amount of each treatment were determined by weighing the barrel, and calculated using the water balance equation [36,37]:

$$
E T=I+W_{0}-W_{\mathrm{h}}
$$

where $I$ is the total irrigation amount $(\mathrm{kg})$, and $W_{0}$ and $W_{\mathrm{h}}$ are the water storage capacity in the barrel at transplantation and harvest, respectively $(\mathrm{kg})$. In this experiment, the leakage and runoff were not considered.
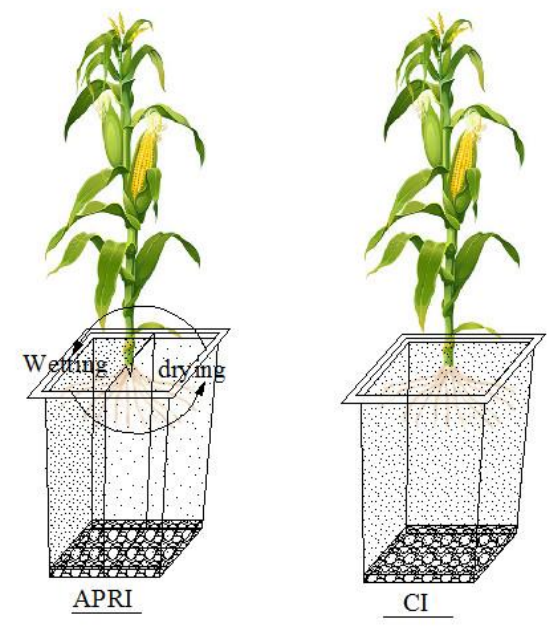

Figure 2. Layout of the two irrigation methods. 


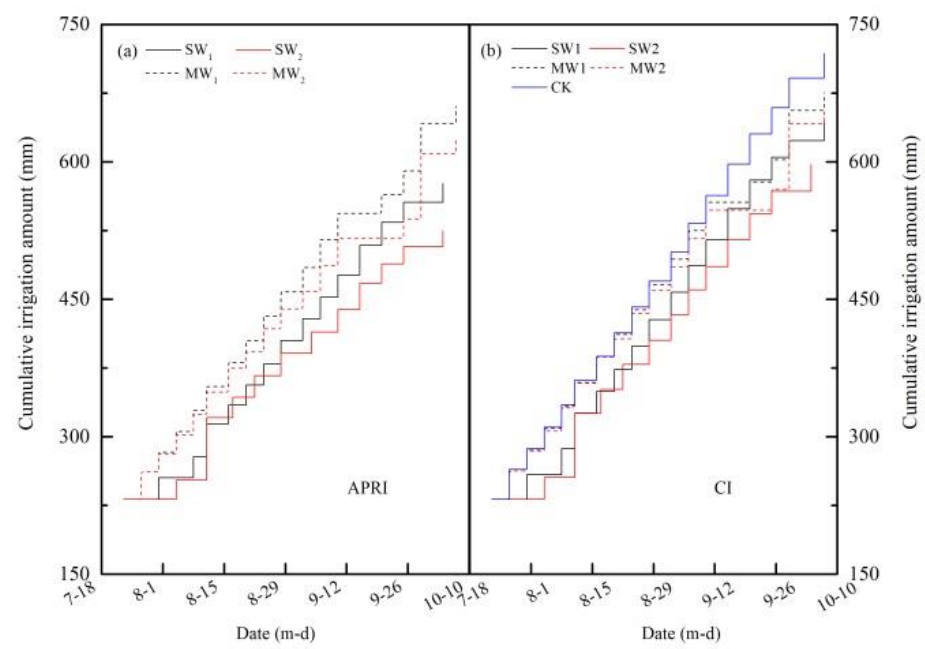

Figure 3. Irrigation schedule during the maize growing seasons under APRI (a) and CI (b).

\subsection{Measurements and Calculations}

\subsubsection{Plant Height, Leaf Related Indexes, and Dry Matter Amount}

Root samples were destructively taken on 18 August (i.e., 42 days), 27 August (i.e., 60 days), 14 September (i.e., 76 days), 29 September (i.e., 91 days), and 12 October (i.e., 105 days) in each treatment. Due to the heavy workload, roots were only taken from one barrel at the first four sampling stages and three barrels were sampled at the harvest stage. The root was sampled by the layering method. A total of five soil layers were taken every $10 \mathrm{~cm}$ of the soil column in the barrel (i.e., 0-10, 10-20, 20-30, 30-40, and 40-50 cm). As for APRI, roots were sampled separately in dry and wet parts of the barrel, and the sum of the root weight of the two parts in the same soil layer was considered to be the total root weight of the layer. The roots were separated and washed. The leaves, stems, cobs, and roots were sampled simultaneously at harvest, and were placed in an oven and dried at $105^{\circ} \mathrm{C}$ for $30 \mathrm{~min}$, before being dried at $75^{\circ} \mathrm{C}$ to a constant weight. Thereafter, roots and other components of each treatment were weighed with an electronic balance (accuracy of 0.0001 and $0.01 \mathrm{~g}$, respectively). The root growth rate was the difference between the two adjacent root dry weights divided by the days at that stage. The plant height and the maximum length and width of leaves were also measured by a ruler. Then, the leaf area $\left(\mathrm{cm}^{2}\right.$ plant $\left.^{-1}\right)$ was calculated by Equation (2) [38]:

$$
L A=L \times W \times 0.75
$$

where $L$ and $W$ are the maximum leaf length and width, respectively. The special leaf area $\left(S L A, \mathrm{~cm}^{2} \mathrm{~g}^{-1}\right)$ was calculated using Equation (3):

$$
S L A=L A / L D W
$$

where $L D W$ is the dry leaf weight $\left(\mathrm{g} \mathrm{plant}^{-1}\right)$.

The leaf area ratio $\left(L A R, \mathrm{~cm}^{2} \mathrm{~g}^{-1}\right)$ was calculated using Equation (4):

$$
L A R=L A / L A S W
$$

where $L S D W$ is the leaf and stem dry weight $\left(\mathrm{g} \mathrm{plant}^{-1}\right)$.

\subsubsection{Yield Traits, Harvest Index $(H I)$, and WUE}

At harvest, the cob length, tip length, and cob circumference were measured with a vernier caliper and ruler, and the grain yield was weighed by an electronic balance 
(accuracy of $0.01 \mathrm{~g}$ ). Grain numbers per cob was counted. HI (\%) was calculated using Equation (5) [39]:

$$
H I=Y / D M A \times 100
$$

where $Y$ is the grain yield ( $\mathrm{g} \mathrm{plant}^{-1}$ ), and $D M A$ is the aboveground dry matter amount $\left(\right.$ g plant $\left.^{-1}\right)$.

WUE was calculated as below.

The water use efficiency based on the dry grain yield $\left(W U E_{Y}, \mathrm{~kg} \mathrm{~m}^{-3}\right)$ was calculated using Equation (6):

$$
W U E_{Y}=Y / E T
$$

where $Y$ is the grain yield $\left(\mathrm{g} \mathrm{plant}^{-1}\right.$ ).

The water use efficiency based on the total biomass $\left(W U E_{B}, \mathrm{~kg} \mathrm{~m}^{-3}\right)$ was calculated using Equation (7):

$$
W U E_{B}=B / E T
$$

where $B$ is the biomass weight $(\mathrm{g})$.

The water use efficiency based on the irrigation amount (IWUE, $\mathrm{kg} \mathrm{m}^{-3}$ ) was calculated using Equation (8) [40]:

$$
I W U E=Y / I
$$

where $I$ is irrigation amount ( $\mathrm{mm} /$ plant).

\subsubsection{Chlorophyll and Carotenoid Content}

At harvest, three cob leaves were collected from each treatment and extracted with the $95 \%$ ethanol. The chlorophyll and carotenoid contents in leaves were determined by an ultraviolet spectrophotometer at 665, 649, and $470 \mathrm{~nm}$ (with 95\% ethanol as a blank control), and the calculation equations were as displayed in Equation (9) [41]:

$$
\begin{aligned}
& C_{a}=\left(13.95 D_{665}-6.88 D_{649}\right) V / 1000 M \\
& C_{b}=\left(24.96 D_{649}-7.32 D_{665}\right) V / 1000 M \\
& C x \cdot c=\left(4.08 D_{470}-11.56 D_{649}+3.29 D_{665}\right) V / 1000 M \\
& C_{T}=C_{a}+C_{b}
\end{aligned}
$$

2.3.4. Nitrate Nitrogen, Ammonium Nitrogen, Available Phosphorus, and Available Potassium

Soil samples were passed through a $5 \mathrm{~mm}$ sieve. Five grams of fresh soil was weighed and extracted with the $2 \mathrm{~mol} \mathrm{~L}^{-1} \mathrm{KCl}$ solution (soil/liquid ratio of 1:10). The nitrate nitrogen and ammonium nitrogen were measured by a continuous flow analyzer (Auto Analyzer-III, Bran Luebbe, Germany). The other soil samples were air-dried and then passed through a $2 \mathrm{~mm}$ sieve. Five grams of soil was weighed and extracted with the $1 \mathrm{~mol} \mathrm{~L}^{-1}$ neutral $\mathrm{NH}_{4} \mathrm{OAc}$ solution (soil/liquid ratio of 1:10), and the available potassium was measured by an atomic absorption spectrophotometer (AA370MC). Five grams of soil was weighed and extracted with the $0.5 \mathrm{~mol} \mathrm{~L}{ }^{-1} \mathrm{NaHCO}_{3}$ solution (soil/liquid ratio of 1:20), and the available phosphorus was also measured by the continuous flow analyzer. Five grams of soil was weighed and extracted with the distilled water (soil/liquid ratio of 1:5), and the $\mathrm{pH}$ value was then measured by a $\mathrm{pH}$ meter. The soil organic matter was determined by the potassium dichromate-volumetric method.

\subsubsection{Multi-Objective Evaluation Based on the Entropy Weight Method and TOPSIS Method}

The entropy weight method uses information entropy to calculate the entropy weight of each index according to the degree of variation of each index, and then corrects the weight of each index through the entropy weight, thereby obtaining a more objective weight of the index. The Technique for Order Preference by Similarity to Ideal Solution (TOPSIS) is a method of ranking according to the proximity of the evaluation object to the idealized target, which is employed to evaluate the relative advantages and disadvantages of the existing objects. 
(1) Assuming the decision problem has $n$ feasible schemes $\left(f_{i}, i=1,2, \ldots \ldots, n\right)$ and $\mathrm{m}$ targets $\left(X_{j}, j=1,2, \ldots \ldots, m\right)$, the original matrix $R=\left[r_{i j}\right]_{n \times m}$ is constructed and dimensionless processing of the original matrix using the formulas of (10) to obtain the matrix $Y$. Then, the entropy weight of each index is determined.

$$
\begin{gathered}
\mathrm{y}_{i j}=\frac{r_{i j}-\min \left(r_{j}\right)}{\max \left(r_{j}\right)-\min \left(r_{j}\right)}, j=1,2,3, \ldots, \mathrm{m} \\
p_{i j}=\frac{y_{i j}}{\sum_{i=1}^{n} y_{i j}} \\
E_{j}=-\ln (n)^{-1} \sum_{i=1}^{n} p_{i j} \ln \left(p_{i j}\right) \\
W_{j}=\frac{1-E_{j}}{m-\sum E_{j}}
\end{gathered}
$$

where $p_{i j}$ is the characteristic proportion of the $\mathrm{i}$-th evaluation object under the $j$-th index. $E_{j}$ is the entropy value of the $j$-th index.

(2) Normalize the original matrix $\mathrm{R}=\left[r_{i j}\right]_{n \times m}$ to get matrix $\mathrm{B}=\left[b_{i j}\right]_{n \times m}$, and multiply it by the entropy weight to get weight matrix $Z$. Then, calculate the Euclidean distances $\mathrm{Si}^{*}$ and $\mathrm{Si}^{-}$between each target value and the ideal point and the relative closeness $\mathrm{Ci}^{*}$ of each target using Equations (16)-(18). The schemes are sorted according to the relative closeness to form a decision basis.

$$
\begin{aligned}
& \mathrm{b} i j=\frac{r i j}{\sqrt{\sum_{i=1}^{n} r i j^{2}}}, j=1,2, \cdots, m \\
& \mathrm{z} i j=W j b i j \\
& S i^{*}=\sqrt{\sum_{j=1}^{m}\left(z i j-z j^{*}\right)^{2}}, i=1,2, \cdots, n \\
& S i^{-}=\sqrt{\sum_{j=1}^{m}\left(\mathrm{z} i j-z j^{-}\right)^{2}}, i=1,2, \cdots, n \\
& C i^{*}=\frac{S i^{-}}{S i^{*}+S i^{-}},
\end{aligned}
$$

where $z_{j}^{*}$ is a benefit indicator and $z_{j}{ }^{-}$is a cost indicator.

\subsection{Data Analysis}

An analysis of variance (ANOVA) was performed using a conventional linear modelunivariate process in SPSS (Statistical Product and Service Solutions) software. The analysis of variance was conducted with the irrigation method, deficit stage, and irrigation level as the main influencing factors, including two-way and three-way interactions. Using Duncan's multiple range test, any significant difference in all treatments was compared at a significance level of $p=0.05$.

\section{Results}

\subsection{Leaf-Related Indexes}

Neither the irrigation method $\times$ irrigation level nor the irrigation method $\times$ deficit stage $\times$ irrigation level significantly affected the fresh leaf weight, dry leaf weight, LA, SLA, and LAR. However, the deficit stage had significant effects on all of the indicators above 
(Table 3). In comparison to CK, CI at M decreased the fresh leaf weight, dry leaf weight, and LA by $19.2 \%, 15.6 \%$, and $7.6 \%$, respectively. Additionally, CI at S decreased the indicators above by $32.59 \%, 43.69 \%$, and $24.99 \%$, respectively. Meanwhile, APRI at M decreased them by $18.21 \%, 30.23 \%$, and $-0.28 \%$, respectively, and APRI at S decreased them by $29.49 \%$, $41.48 \%$, and $13.4 \%$, respectively. However, APRI and CI showed an increasing trend in SLA and LAR at each deficit stage.

Table 3. Effects of different irrigation levels and deficit stages on the leaf-related indexes of maize under alternate partial root-zone irrigation.

\begin{tabular}{|c|c|c|c|c|c|c|c|}
\hline $\begin{array}{l}\text { Irrigation } \\
\text { Method }\end{array}$ & Deficit Stage & $\begin{array}{l}\text { Irrigation } \\
\text { Level }\end{array}$ & $\begin{array}{c}\text { Fresh leaf } \\
\text { Weight } \\
\text { (g plant }^{-1} \text { ) }\end{array}$ & $\begin{array}{c}\text { Dry leaf } \\
\text { Weight } \\
\text { (g plant }^{-1} \text { ) }\end{array}$ & $\begin{array}{c}\text { Leaf Area } \\
\left(\mathrm{cm}^{2} \text { plant }^{-1}\right)\end{array}$ & $\begin{array}{c}\text { Special Leaf } \\
\text { Area }\left(\mathrm{cm}^{2} \mathrm{~g}^{-1}\right)\end{array}$ & $\begin{array}{l}\text { Leaf Area Ratio } \\
\qquad\left(\mathrm{cm}^{2} \mathrm{~g}^{-1}\right)\end{array}$ \\
\hline \multirow{4}{*}{ APRI } & \multirow[b]{2}{*}{$\mathrm{S}$} & $\mathrm{W}_{1}$ & $53.49 \mathrm{bc}$ & $16.95 \mathrm{~b}$ & $3776 \mathrm{~cd}$ & $222.82 \mathrm{bc}$ & $53.22 \mathrm{ab}$ \\
\hline & & $W_{2}$ & $49.21 \mathrm{c}$ & $13.19 \mathrm{~cd}$ & $3325.5 \mathrm{e}$ & $252.08 \mathrm{a}$ & $54.28 \mathrm{a}$ \\
\hline & \multirow{2}{*}{$\mathrm{M}$} & $\mathrm{W}_{1}$ & $71.97 \mathrm{a}$ & $18.51 \mathrm{~b}$ & $4231.8 \mathrm{a}$ & $228.6 \mathrm{~b}$ & $43.72 \mathrm{c}$ \\
\hline & & $\mathrm{W}_{2}$ & $47.16 \mathrm{c}$ & $17.42 \mathrm{~b}$ & 3992 abc & $229.19 \mathrm{~b}$ & $43.27 \mathrm{c}$ \\
\hline \multirow{4}{*}{$\mathrm{CI}$} & \multirow{2}{*}{$S$} & $\mathrm{~W}_{1}$ & $55.46 \mathrm{bc}$ & $16.43 \mathrm{bc}$ & 3520.4 de & $214.2 \mathrm{bc}$ & $50.16 \mathrm{~b}$ \\
\hline & & $\mathrm{W}_{2}$ & $42.73 \mathrm{c}$ & $12.57 \mathrm{~d}$ & $2630.8 \mathrm{f}$ & 209.25 c & $44.29 \mathrm{c}$ \\
\hline & \multirow[b]{2}{*}{$\mathrm{M}$} & $\mathrm{W}_{1}$ & $65.19 \mathrm{ab}$ & $24.07 \mathrm{a}$ & $3862.5 \mathrm{bc}$ & $160.47 \mathrm{e}$ & $40.25 \mathrm{c}$ \\
\hline & & $W_{2}$ & $52.44 \mathrm{bc}$ & $19.4 \mathrm{~b}$ & $3712 \mathrm{~cd}$ & $191.39 \mathrm{~d}$ & $43.37 \mathrm{c}$ \\
\hline $\mathrm{CI}$ & All & $\mathrm{W}_{0}$ & $72.83 \mathrm{a}$ & $25.75 \mathrm{a}$ & $4100.3 \mathrm{ab}$ & $159.21 \mathrm{e}$ & $41.92 \mathrm{c}$ \\
\hline \multicolumn{3}{|c|}{ Irrigation method } & ns & ns & $* *$ & $*$ & $*$ \\
\hline \multicolumn{3}{|c|}{ Deficit stage } & $* *$ & $* *$ & $* *$ & $* *$ & $* *$ \\
\hline \multicolumn{3}{|c|}{ Irrigation level } & $* *$ & $* *$ & $* *$ & ns & $* *$ \\
\hline \multicolumn{3}{|c|}{ Irrigation method $\times$ Deficit stage } & ns & $*$ & ns & ns & ns \\
\hline \multicolumn{3}{|c|}{ Irrigation method $\times$ Irrigation level } & ns & ns & ns & ns & ns \\
\hline \multicolumn{3}{|c|}{ Deficit stage $\times$ Irrigation level } & ns & ns & $* *$ & $* *$ & $* *$ \\
\hline \multicolumn{3}{|c|}{$\begin{array}{c}\text { Irrigation method } \times \text { Deficit stage } \times \\
\text { Irrigation level }\end{array}$} & ns & ns & ns & ns & ns \\
\hline
\end{tabular}

Note: Different letters behind the values denote significant differences at $p<0.05$ according to the Duncan test. ${ }^{*}$ means significant difference $(p<0.05),{ }^{* *}$ means extremely significant difference $(p<0.01)$, and ns means no significant difference $(p>0.05)$.

There were obvious effects of the irrigation method and deficit stage $\times$ irrigation level on LA, SLA, and LAR, but the fresh leaf weight and dry leaf weight were hardly influenced by them. Apart from SLA, the irrigation level had a significant impact on all of the other indicators (Table 3). Compared to $\mathrm{W}_{1}, \mathrm{~W}_{2}$ decreased the fresh leaf weight, dry leaf weight, LA, and LAR by $22.17 \%, 17.61 \%, 11.24 \%$, and $1.14 \%$, respectively.

Furthermore, the irrigation method $\times$ deficit stage had a significant effect on the dry leaf weight, but it had no significant effect on the other indicators (Table 3). AMW 1 and CK had a higher fresh leaf weight and LA (71.97 and $72.83 \mathrm{~g}$ and 4231.8 and $4100.3 \mathrm{~cm}^{2}$, respectively) and the highest SLA and LAR were observed under ASW 2 (252.08 and $54.28 \mathrm{~cm}^{2} / \mathrm{g}$, respectively). $\mathrm{CMW}_{1}$ and $\mathrm{CK}$ had a greater dry leaf weight (24.07 and $25.75 \mathrm{~g}$, respectively). The smallest fresh and dry leaf weight were observed under $\mathrm{CSW}_{2}(42.73$ and $12.57 \mathrm{~g}$, respectively). Meanwhile, the smallest SLA was obtained in CK $\left(159.21 \mathrm{~cm}^{2} / \mathrm{g}\right)$ and the smallest LAR was observed under $\mathrm{CMW}_{1}\left(40.25 \mathrm{~cm}^{2} / \mathrm{g}\right)($ Table 3$)$.

\subsection{Plant Height, Aboveground Dry Matter Accumulation, and Chlorophyll and Carotenoid Content}

There was a significant effect of the irrigation method, deficit stage, and irrigation level on the plant height and aboveground dry matter amount, but no significant impact of the irrigation method $\times$ irrigation level and the three-way interactions on them (Table 4).

Data collected at harvest suggested that at the same irrigation method and deficit stage, the plant height and aboveground dry matter amount increased with the increase of the irrigation level, but no significant difference was found in the plant height. Compared to $\mathrm{CK}, \mathrm{W}_{1}$ and $\mathrm{W}_{2}$ under $\mathrm{CI}$ decreased the plant height and dry matter amount by $17.6 \%$ and $19.1 \%$ and $19.4 \%$ and $27.8 \%$, respectively, and decreased by $11.8 \%$ and $15.1 \%$ and 
$13.5 \%$ and $24 \%$ under APRI, respectively. Regarding the irrigation method, APRI recorded a significantly higher value for the aboveground dry matter amount $(7.80 \%$, average $)$ compared with CI under the same irrigation level and deficit stage. APRI and CI decreased the plant height and dry matter amount by $13.4 \%$ and $18.3 \%$ and $18.7 \%$ and $23.1 \%$ compared to $\mathrm{CK}$, respectively. Under the same irrigation method and irrigation level, the plant height and aboveground dry matter amount of water deficit at $\mathrm{S}$ were noticeably lower than at $\mathrm{M}$. Relative to CK, CI decreased the plant height and dry matter amount by $34.6 \%$ and $2.1 \%$ and $33.4 \%$ and $13.7 \%$, respectively, and APRI declined by $25.8 \%$ and $1.1 \%$ and $29.2 \%$ and $8.3 \%$, respectively, when water deficit occurred at S and M (Figure $4 a, b)$.

Table 4. Significance levels ( $p$ values) of the effects of the irrigation method, deficit stage, and irrigation level on the plant height, dry matter, chlorophyll, carotenoids, ET, WUE, , IWUE, and WUE $E_{B}$.

\begin{tabular}{|c|c|c|c|c|}
\hline Variation Source & Plant Height & Dry Matter & Chlorophyll & Carotenoids \\
\hline Irrigation method & $* *$ & ** & ** & $* *$ \\
\hline Deficit stage & $* *$ & $* *$ & $* *$ & ** \\
\hline Irrigation level & * & ** & ** & ** \\
\hline Irrigation method $\times$ Deficit stage & ** & ns & ns & ** \\
\hline Irrigation method $\times$ Irrigation level & ns & ns & ns & * \\
\hline Deficit stage $\times$ Irrigation level & ns & $* *$ & $* *$ & ns \\
\hline Irrigation method $\times$ Deficit stage $\times$ Irrigation level & ns & ns & ns & ns \\
\hline Variation source & ET & WUE $_{Y}$ & IWUE & WUE $_{B}$ \\
\hline Irrigation method & ** & ** & ** & $* *$ \\
\hline Deficit stage & ** & ** & ** & ** \\
\hline Irrigation level & ** & ns & ** & ** \\
\hline Irrigation method $\times$ Deficit stage & $\mathrm{ns}$ & $* *$ & $* *$ & ns \\
\hline Irrigation method $\times$ Irrigation level & $* *$ & ns & ns & ns \\
\hline Deficit stage $\times$ Irrigation level & * & ns & ns & ** \\
\hline Irrigation method $\times$ Deficit stage $\times$ Irrigation level & ns & $\mathrm{ns}$ & ns & * \\
\hline
\end{tabular}

Note: * means significant difference $(p<0.05),{ }^{* *}$ means extremely significant difference $(p<0.01)$, and ns means no significant difference $(p>0.05)$.

With regard to the chlorophyll and carotenoid contents, the impact of the irrigation method, deficit stage, and irrigation level on them was significant, while the interaction of the irrigation method, deficit stage, and irrigation level had no significant effect on them (Table 4).

The chlorophyll and carotenoid contents were higher under CI than APRI. Compared to CK, CI and APRI significantly reduced the chlorophyll and carotenoid content by $13.7 \%$ and $23.1 \%$ and $11.3 \%$ and $20.3 \%$, respectively. Deficit at M reduced the leaf chlorophyll and carotenoid concentration for the same irrigation method and irrigation level. Compared to $\mathrm{CK}, \mathrm{M}$ and S under CI decreased the chlorophyll and carotenoid contents by $24.5 \%$ and $2.9 \%$ and $12.9 \%$ and $9.8 \%$, respectively. Moreover, they decreased by $32.5 \%$ and $13.7 \%$ and $25.5 \%$ and $15.2 \%$ under APRI, respectively. Overall, the chlorophyll and carotenoid contents of $\mathrm{W}_{1}$ were higher than those of $\mathrm{W}_{2}$ (Figure $4 \mathrm{c}, \mathrm{d}$ ). 


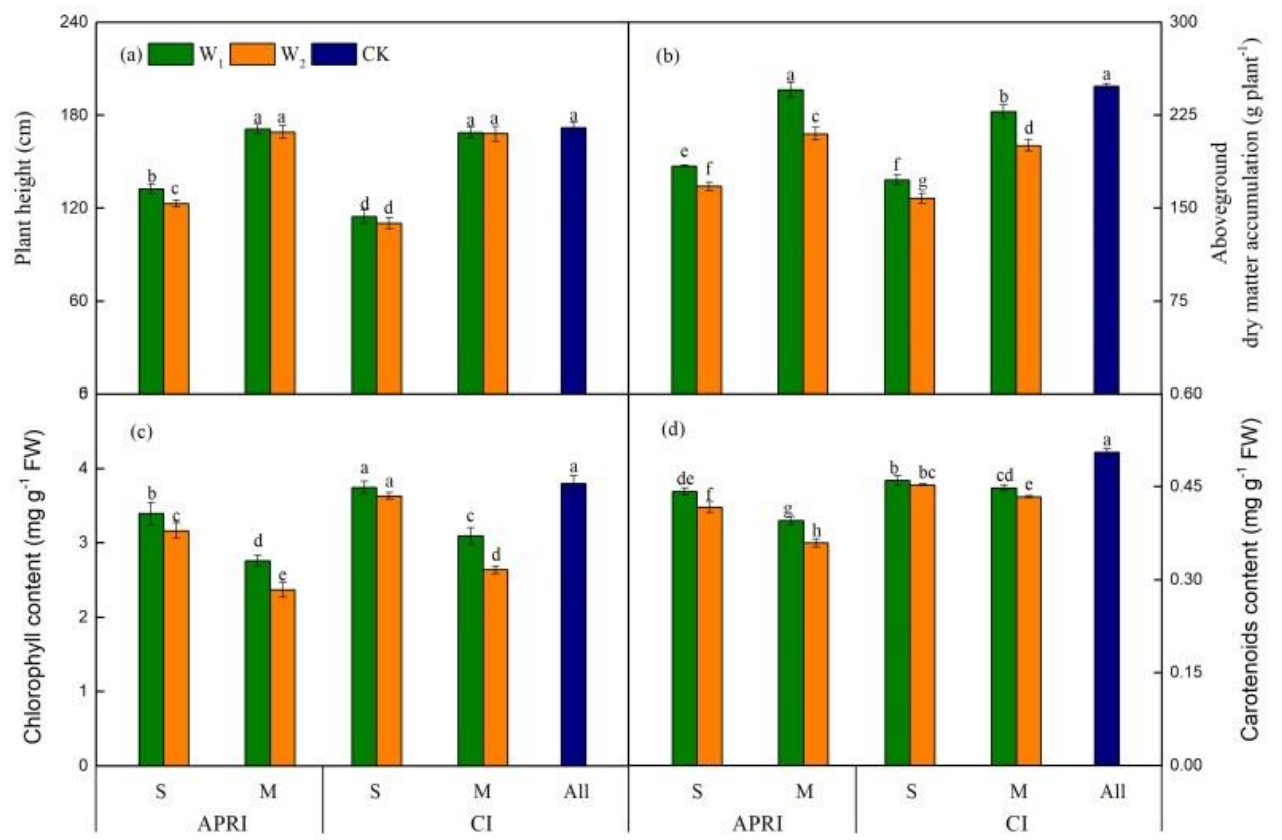

Figure 4. Effects of different irrigation levels and deficit periods on the plant height (a), aboveground matter accumulation (b), and chlorophyll (c) and carotenoid content (d) of maize under alternate partial root-zone irrigation. Different letters on top of the bar denote significant differences at $p<0.05$ according to the Duncan test.

\subsection{Root Dry Weight}

The general trends of the root dry weight throughout the growth season of maize were similar among all treatments, increasing first and then decreasing over time, with varying rates (Figure 5). Therefore, the irrigation method, deficit stage, and irrigation level did not change the general trend of the maize root dry weight. The root growth rate was largest at the seedling stage. The root dry weight of all treatments reached the peak at the end of the milking stage (9/29). At harvest (10/12), $\mathrm{ASW}_{2}$ had the lowest root growth rate, which was significantly similar to that of $\mathrm{CSW}_{2}$, causing a similar root dry weight in both treatments (5.0923 and $5.0090 \mathrm{~g}$, respectively). Overall, the largest root dry weight was in $\mathrm{CK}$, while the root growth rate was not always the largest. Regardless of the irrigation level and irrigation method, the root dry weight of full irrigation was greater than that of deficit irrigation at the seedling stage, while the root growth rate after rewatering was higher than that of full irrigation.

In terms of deficit at the same growth stage, the root dry weight under APRI was greater than that under CI for the first four stages, but lower than that under CI at harvest at the same irrigation level. Under the same irrigation method and irrigation level, the root dry weight of deficit at $\mathrm{M}$ was significantly higher than that at $\mathrm{S}$. Compared to that at $\mathrm{M}$, the average root dry weight at S was decreased by $43.94 \%$ and $18.50 \%$ under APRI and $\mathrm{CI}$, respectively. Under the same irrigation method and deficit stage, the root dry weight decreased with the decrease of the irrigation amount. The highest root growth rate was observed on 18 August, which coincided with the smallest root dry weight (Figure 5).

At harvest, the distribution of roots in the soil profile was the same among different treatments, with $53 \%$ of roots in the $0 \sim 10 \mathrm{~cm}$ soil layer. The distribution of roots was largely affected by the deficit stage, irrigation method, and irrigation level. Specifically, water deficit that occurred at $S$ had a greater impact on root growth. Under the same irrigation method and deficit stage, the root dry weight in each soil layer of $\mathrm{W}_{1}$ was remarkably higher than that of $\mathrm{W}_{2}$, with APRI and CI being $104.29 \%$ and $35.86 \%$ higher on average, respectively. Compared to $\mathrm{CK}, \mathrm{W}_{1}$ and $\mathrm{W}_{2}$ reduced the root dry weight by $16.7 \%$ and $26.9 \%$, respectively. When the same irrigation level was applied, the root dry weight in the $0 \sim 10 \mathrm{~cm}$ soil layer under deficit irrigation at $S$ was greater than that at $M$ under APRI, 
while the root dry weight in the 10 50 cm layer under deficit irrigation at $\mathrm{S}$ was lower than that at $\mathrm{M}$. In comparison to $\mathrm{CK}$, deficit at $\mathrm{S}$ and $\mathrm{M}$ decreased the root dry weight by $57.9 \%$ and $35 \%$, respectively. The root dry weight in each layer at $\mathrm{S}$ was $61.2 \%, 15.4 \%, 12.2 \%$, $8.6 \%$, and $2.7 \%$, and that at $\mathrm{M}$ was $43.3 \%, 21.4 \%, 16.2 \%, 12.4 \%$, and $6.7 \%$, respectively. As for the irrigation method, APRI and CI reduced the root dry weight by $44 \%$ and $48.9 \%$ for $\mathrm{CK}$, respectively. Apart from the $0 \sim 10 \mathrm{~cm}$ soil layer, the root weight of the other soil layers under APRI was greater than that under $\mathrm{CI}$, but the proportion of roots in each soil layer to the total roots displayed no large difference between APRI and CI, except for the $0 \sim 10 \mathrm{~cm}$ soil layer (Figure 6).
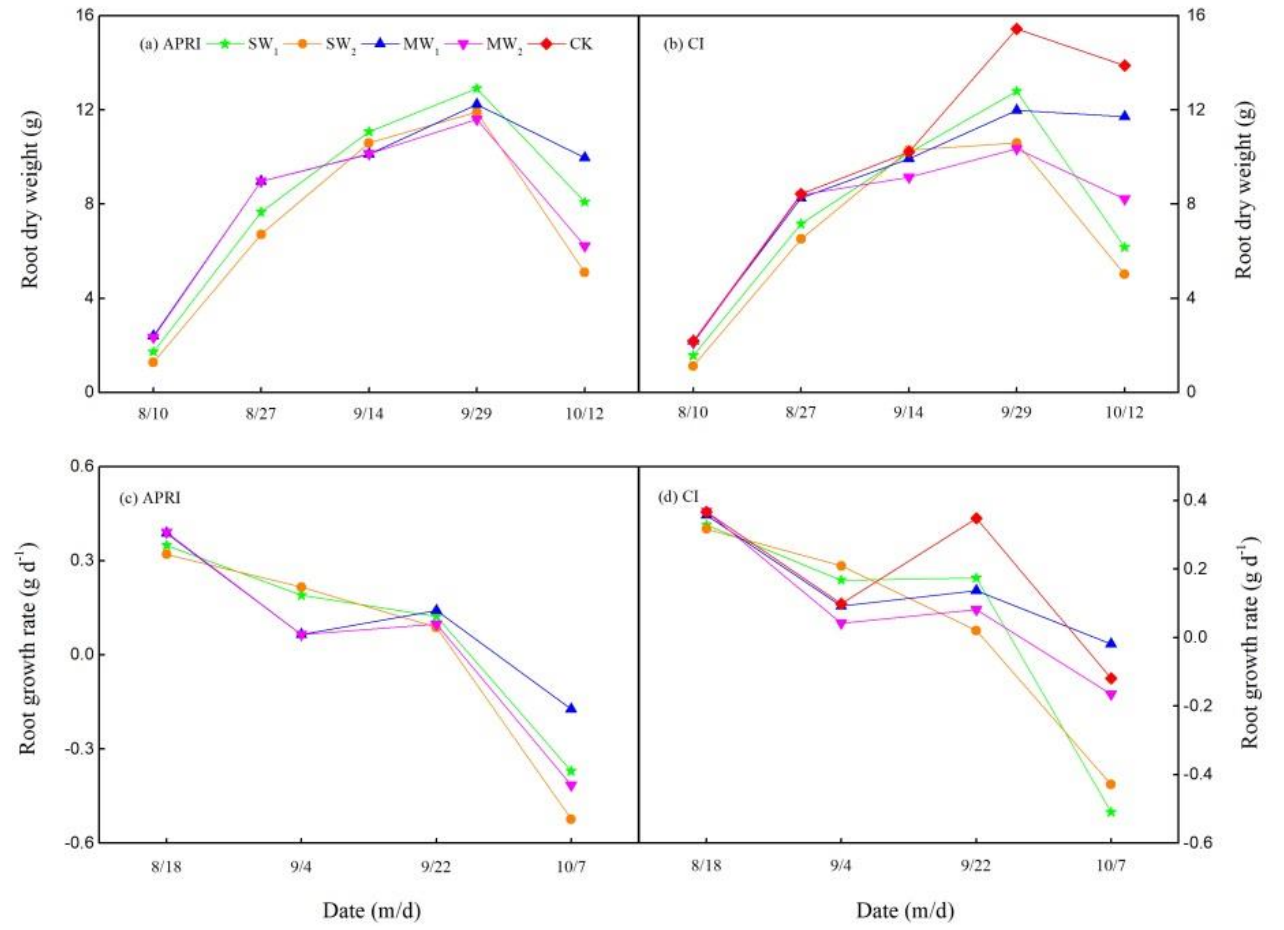

Figure 5. Root dry weight $(\mathbf{a}, \mathbf{b})$ and root growth rate $(\mathbf{c}, \mathbf{d})$ in the whole soil profile $(0 \sim 50 \mathrm{~cm})$ of maize in $\mathrm{SW}_{1}, \mathrm{SW}_{2}, \mathrm{MW}_{1}, \mathrm{MW}_{2}$, and $\mathrm{CK}$ treatments throughout the growing season.
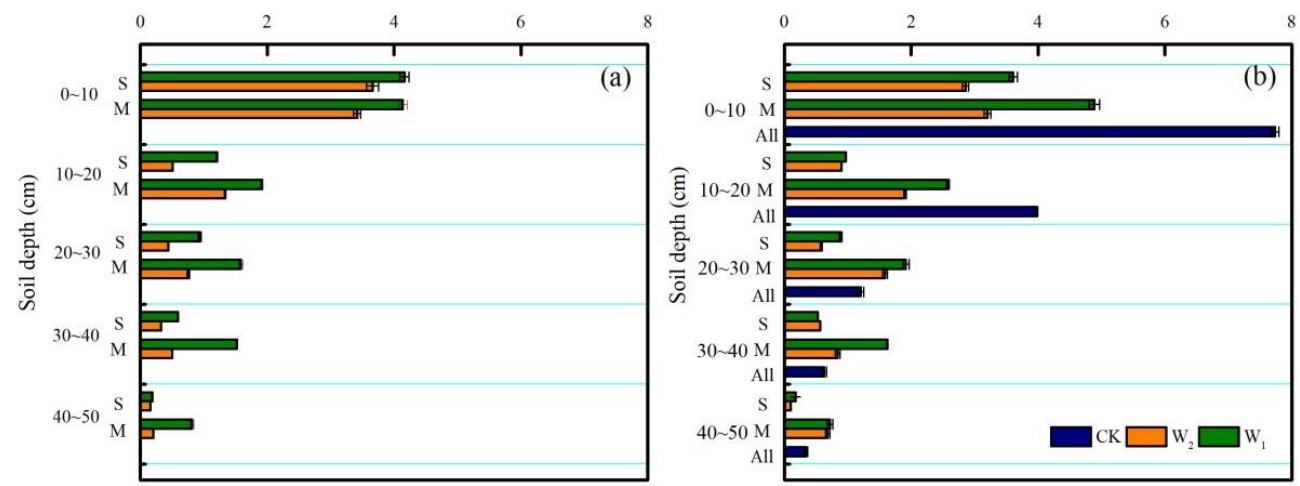

Figure 6. Distribution of the root dry weight in different soil layers at harvest under APRI (a) and CI (b).

\subsection{Yield Traits}

There were significant effects of the irrigation method, deficit stage, and irrigation level on the tip length, grain number per cob, and grain yield, but no significant effects of their two- or three-way interaction on the cob circumference, grain number per cob, grain yield, and HI were obtained (Table 5). 
Table 5. Effects of different irrigation levels and deficit stages on the grain yield and its traits of maize under alternate partial root-zone irrigation.

\begin{tabular}{|c|c|c|c|c|c|c|c|c|}
\hline $\begin{array}{l}\text { Irrigation } \\
\text { Method }\end{array}$ & $\begin{array}{l}\text { Deficit } \\
\text { Stage }\end{array}$ & $\begin{array}{l}\text { Irrigation } \\
\text { Level }\end{array}$ & $\begin{array}{c}\text { Cob } \\
\text { Length } \\
\text { (cm) }\end{array}$ & $\begin{array}{l}\text { Tip Length } \\
\text { (cm) }\end{array}$ & $\begin{array}{c}\text { Cob } \\
\text { Circumference } \\
\text { (cm) }\end{array}$ & $\begin{array}{c}\text { Grain } \\
\text { Number } \\
\text { Per Cob (n) }\end{array}$ & $\begin{array}{l}\text { Grain } \\
\text { Yield } \\
\text { (g/plant) }\end{array}$ & $\begin{array}{l}\text { HI } \\
(\%)\end{array}$ \\
\hline \multirow{4}{*}{ APRI } & \multirow[t]{2}{*}{$S$} & $\mathrm{~W}_{1}$ & $18.1 \mathrm{a}$ & $0.5 \mathrm{e}$ & $12.71 \mathrm{a}$ & 388 a & $73.66 \mathrm{a}$ & $40.03 a$ \\
\hline & & $\mathrm{W}_{2}$ & $17.44 \mathrm{a}$ & $0.7 \mathrm{~d}$ & $12.23 \mathrm{a}$ & $350 \mathrm{c}$ & $63.56 \mathrm{c}$ & $38.43 \mathrm{ab}$ \\
\hline & \multirow[b]{2}{*}{ M } & $\mathrm{W}_{1}$ & $17.8 \mathrm{a}$ & $2.2 \mathrm{~b}$ & $13.5 \mathrm{a}$ & $322 \mathrm{~d}$ & $60.81 \mathrm{~cd}$ & $36.17 \mathrm{~b}$ \\
\hline & & $\mathrm{W}_{2}$ & $15.8 \mathrm{a}$ & $3.1 \mathrm{a}$ & $13.1 \mathrm{a}$ & $290 \mathrm{e}$ & 54.78 de & $29.6 \mathrm{c}$ \\
\hline \multirow{4}{*}{ CI } & \multirow{2}{*}{$S$} & $\mathrm{~W}_{1}$ & $17.75 \mathrm{a}$ & $0.3 \mathrm{f}$ & $13.01 \mathrm{a}$ & $327 \mathrm{~d}$ & $66.38 \mathrm{bc}$ & $37.97 \mathrm{ab}$ \\
\hline & & $\mathrm{W}_{2}$ & $18.3 \mathrm{a}$ & 0.4 ef & $13.44 \mathrm{a}$ & $312 \mathrm{~d}$ & $56.2 \mathrm{~d}$ & $35.67 \mathrm{~b}$ \\
\hline & \multirow{2}{*}{ M } & $\mathrm{W}_{1}$ & $16 \mathrm{a}$ & $1.7 \mathrm{c}$ & $13.62 \mathrm{a}$ & $289 \mathrm{e}$ & $55.69 \mathrm{de}$ & $26.13 \mathrm{~cd}$ \\
\hline & & $\mathrm{W}_{2}$ & $16.7 \mathrm{a}$ & $2.1 \mathrm{~b}$ & $12.81 \mathrm{a}$ & $257 \mathrm{f}$ & $49.59 \mathrm{e}$ & $24.73 \mathrm{~d}$ \\
\hline $\mathrm{CI}$ & All & $\mathrm{W}_{0}$ & $18.6 \mathrm{a}$ & $0.8 \mathrm{~d}$ & $13.42 \mathrm{a}$ & $370 \mathrm{~b}$ & $70.23 \mathrm{ab}$ & $28.30 \mathrm{~cd}$ \\
\hline \multicolumn{3}{|c|}{ Irrigation method } & ns & $* *$ & ns & $* *$ & $* *$ & ns \\
\hline \multicolumn{3}{|c|}{ Deficit stage } & $* *$ & $* *$ & ns & $* *$ & $* *$ & $* *$ \\
\hline \multicolumn{3}{|c|}{ Irrigation level } & ns & ** & ns & ** & $* *$ & ns \\
\hline \multicolumn{3}{|c|}{ Irrigation method $\times$ Deficit stage } & ns & ** & ns & ns & ns & ns \\
\hline \multirow{2}{*}{\multicolumn{3}{|c|}{$\begin{array}{l}\text { Irrigation method } \times \text { Irrigation level } \\
\text { Deficit stage } \times \text { Irrigation level }\end{array}$}} & $* *$ & $* *$ & ns & ns & ns & ns \\
\hline & & & ns & ** & ns & ns & ns & ns \\
\hline \multicolumn{3}{|c|}{$\begin{array}{c}\text { Irrigation method } \times \text { Deficit stage } \times \\
\text { Irrigation level }\end{array}$} & ns & * & ns & ns & ns & ns \\
\hline
\end{tabular}

Note: Different letters behind the values denote significant differences at $p<0.05$ according to the Duncan test. ${ }^{*}$ means significant difference $(p<0.05),{ }^{* *}$ means extremely significant difference $(p<0.01)$, and ns means no significant difference $(p>0.05)$.

There was no significant difference in cob length and circumference among different treatments. For the same irrigation method and deficit stage, there was no significant difference in $\mathrm{HI}$ between different irrigation levels. The highest $\mathrm{HI}$ was obtained in $\mathrm{ASW}_{1}$, $\mathrm{ASW}_{2}$, and $\mathrm{CSW}_{1}$. However, the grain yield of $\mathrm{W}_{1}$ was significantly higher than that of $\mathrm{W}_{2}$ due to the increased grain number per cob and reduced tip length. Because of the shorter tip length and larger grain number per cob, the grain yield was the largest in $\mathrm{ASW}_{1}$ and CK. For the same irrigation method and irrigation level, deficit at $\mathrm{M}$ significantly increased the tip length, causing a reduction of the grain yield and HI. Compared to $\mathrm{CK}$, deficit irrigation that occurred at $\mathrm{S}$ and $\mathrm{M}$ under $\mathrm{CI}$ decreased the grain yield by $12.7 \%$ and $25 \%$, respectively. APRI decreased $2.3 \%$ and $17.7 \%$, respectively. Deficit at M produced a longer tip length, causing a lower grain yield. At the same deficit stage and irrigation level, when water deficit occurred at $\mathrm{M}$, the grain yields of both irrigation methods were not different. In comparison to CK, APRI and CI decreased the grain yield by $10.0 \%$ and $18.9 \%$, respectively (Table 5).

\subsection{ET, WUEY, IWUE, and WUE $E_{B}$}

The irrigation method and deficit stage significantly affected $E T, W U E_{Y}, I W U E$, and $W U E_{B}$. Additionally, there were significant impacts of the irrigation method $\times$ deficit stage on WUEY and IWUE, but the other two- and three-way interactions exerted no significant influence on these two indicators (Table 4).

When the irrigation method and deficit stage were the same, the $E T$ and $W U E_{B}$ of $W_{1}$ were higher compared with those of $\mathrm{W}_{2}$. In comparison to CI, ET under APRI was decreased by $14.99 \%, 19.37 \%, 8.43 \%$, and $15.77 \%$ in $\mathrm{ASW}_{1}, \mathrm{ASW}_{2}, \mathrm{AMW}_{1}$, and $\mathrm{AMW}_{2}$, respectively. $E T$ and $W U E_{B}$ under deficit at $\mathrm{M}$ were significantly higher than that those at $\mathrm{S}$ when the same irrigation method and irrigation level were used. Compared with $\mathrm{CK}$, water deficit at $\mathrm{S}$ and $\mathrm{M}$ under APRI reduced ET by $17 \%$ and $12 \%$, respectively. Deficit in the seedling and milking stage under CI reduced ET by $30 \%$ and $17.6 \%$, respectively, and by $41.9 \%$ and $27.6 \%$ under APRI, respectively (Figure 7 a,d). Under the same irrigation method and deficit stage, no differences in $W U E_{Y}$ and IWUE were observed between $W_{1}$ 
and $W_{2}$. However, the $W U E_{B}$ of $W_{1}$ under deficit irrigation at $\mathrm{M}$ was significantly higher than that of $W_{2}$. Under the same irrigation method and irrigation level, the WUE,$I W U E$, and $W U E_{B}$ of water deficit at $\mathrm{M}$ were significantly lower than that at $\mathrm{S}$. In addition, WUEY under APRI was significantly larger than that of CI when the deficit stage and deficit level were the same, indicating that APRI was conducive to the increase of $W U E_{Y}$. ASW exhibited significantly higher $W U E_{Y}$ and IWUE values (1.72 and $1.288 \mathrm{~kg} / \mathrm{m}^{3}$, respectively) compared to others, and produced larger $W U E_{B}$. Compared to CK, APRI and CI decreased ET by $34.7 \%$ and $23.8 \%$, respectively. APRI obtained higher $W U E_{Y}, I W U E$, and $W U E_{B}$ values than $C I$. As for WUE, APRI and CI increased $W U E_{Y}$ by $41 \%$ and $7.7 \%$, respectively. APRI increased IWUE and $W U E_{B}$ by $8.8 \%$ and $25.5 \%$, respectively, while CI decreased them by $9.45 \%$ and $1.5 \%$, respectively (Figure 7 ).
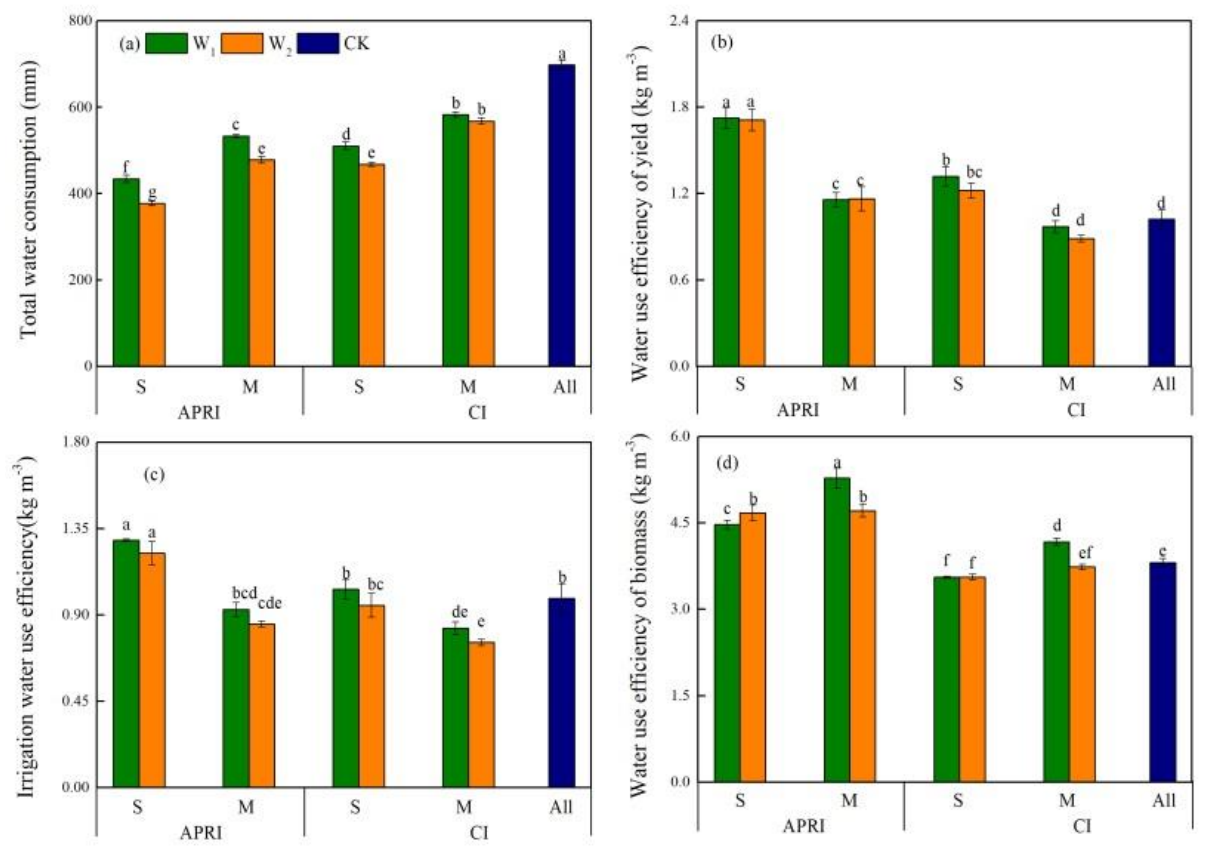

Figure 7. Effects of different irrigation levels and deficit stages on the $E T(\mathbf{a}), W U E_{Y}(\mathbf{b}), \operatorname{IWUE}(\mathbf{c})$, and $W U E_{B}(\mathbf{d})$ of maize under alternate partial root-zone irrigation. Different letters on top of the bar denote significant differences at $p<0.05$ according to the Duncan test.

\subsection{Multi-Objective Evaluation}

The yield reflects the effective productivity of a crop. The dry matter is the product of plant photosynthesis. The water use efficiency is an indicator of the efficiency of the process of water absorption and utilization, which is a hotspot in agricultural research in semi-arid and semi-humid regions. The yield $\left(X_{1}\right)$, dry matter accumulation $\left(X_{2}\right), W W_{Y}$ $\left(X_{3}\right)$, and $\mathrm{WUE}_{B}\left(X_{4}\right)$ under each treatment $\left(X_{j}, j=1,2,3,4\right)$ were constructed to produce the original matrix.

The order of each treatment from superior to inferior was $\mathrm{ASW}_{1}>\mathrm{ASW}_{2}>\mathrm{AMW}_{1}>$ $\mathrm{AMW}_{2}>\mathrm{CK}>\mathrm{CSW}_{1}>\mathrm{CMW}_{1}>\mathrm{CSW}_{2}>\mathrm{CMW}_{2}$ (Table 6). Under APRI, when $\mathrm{W}_{1}$ occurred at $\mathrm{S}$, multi-objective optimization was obtained. 
Table 6. The Euclidean distances $S_{i}{ }^{*}$ and $S_{i}{ }^{-}$between each target value and the ideal point and the relative closeness $C_{i}^{*}$ of each target.

\begin{tabular}{ccccccc}
\hline Irrigation Method & Deficit Stage & Irrigation Level & $S_{i}{ }^{*}$ & $S_{i}{ }^{-}$ & $C_{i}{ }^{*}$ & Rank \\
\hline \multirow{3}{*}{ APRI } & \multirow{2}{*}{$\mathrm{S}$} & $\mathrm{W}_{1}$ & 0.032 & 0.066 & 0.671 & 1 \\
& & $\mathrm{~W}_{2}$ & 0.036 & 0.063 & 0.638 & 2 \\
\cline { 2 - 7 } & \multirow{2}{*}{$\mathrm{M}$} & $\mathrm{W}_{1}$ & 0.040 & 0.059 & 0.599 & 3 \\
& \multirow{2}{*}{$\mathrm{S}$} & $\mathrm{W}_{2}$ & 0.046 & 0.041 & 0.466 & 4 \\
\hline \multirow{3}{*}{$\mathrm{CI}$} & $\mathrm{W}_{1}$ & 0.060 & 0.034 & 0.361 & 6 \\
& \multirow{2}{*}{$\mathrm{M}$} & $\mathrm{W}_{2}$ & 0.068 & 0.023 & 0.254 & 8 \\
\hline & \multirow{2}{*}{$\mathrm{MI}$} & $\mathrm{W}_{1}$ & 0.061 & 0.032 & 0.345 & 7 \\
& \multirow{2}{*}{$\mathrm{All}$} & $\mathrm{W}_{2}$ & 0.075 & 0.017 & 0.185 & 9 \\
\hline & & $\mathrm{W}_{0}$ & 0.060 & 0.042 & 0.409 & 5 \\
\hline
\end{tabular}

\section{Discussion}

\subsection{Plant Height, Leaf-Related Indexes, and Dry Matter}

Previous results showed that APRI reduced the plant height, leaf area, and total dry matter amount compared with CI [42,43]. In this study, when deficit irrigation occurred at $\mathrm{S}$, the plant height, leaf area, and aboveground dry matter amount under APRI were significantly higher than those under $\mathrm{CI}$ at the same irrigation level. Meanwhile, when $\mathrm{W}_{2}$ occurred at $\mathrm{M}$, there were no significant differences in the leaf area and dry matter amount between APRI and CI. This difference can be partially explained by the fact that the temperature at the seedling stage was relatively higher and the evaporation was greater. APRI reduced ET compared to CI, which in turn affected maize growth. Wang et al. [8] showed that, compared with CI, the grain yield was not affected by APRI, while the total biomass amount was greatly decreased by APRI. We found that the plant height, leaf area, leaf chlorophyll concentration, and aboveground dry matter amount of $W_{1}$ were remarkably greater than those of $\mathrm{W}_{2}$ at maturity for the same irrigation method and deficit stage, which generally agreed with previous studies [44-48]. Properly reducing the amount of irrigation at the seedling stage contributed to synthesis of the dry matter amount at the final stage [26]. Xing et al. [49] demonstrated that water deficit at the seedling stage inhibited the growth of plant height, leaf area, and aboveground dry matter. Water shortage at the milking stage did not remarkably impact the plant height, but it had a significant influence on the leaf area and dry matter amount. A water shortage occurred at the jointing stage, which inhibited the expansion of the leaf area and had the greatest impact on the maize leaf area index [50,51]. We also found that the plant height, leaf area, and aboveground dry matter amount under water deficit at $M$ were remarkably greater than those at $S$ under the same irrigation method and irrigation level. A water shortage at the seedling stage inhibited the maize growth.

\subsection{Chlorophyll and Carotenoid Content}

The photosynthetic rate increased with the increase in the leaf chlorophyll concentration, and the degradation of leaf chlorophyll directly caused the photosynthetic rate to be significantly decreased [52,53]. APRI had a slight impact on the chlorophyll and carotenoid content from the jointing to tasseling stage [53,54]. Fu et al. [55] found that the effects of different irrigation methods and levels on the maize carotenoid and chlorophyll concentration at the middle jointing stage, late jointing stage, and tasseling stage were not significant. However, we found a significant impact of the irrigation method, deficit stage, and irrigation level on the chlorophyll content at maturity. At the same deficit stage and irrigation level, the leaf chlorophyll concentration under APRI was significantly lower than that under $\mathrm{CI}$ at maturity. The discrepancy between the results may be explained by the difference in the water deficit stage and duration. 


\subsection{Root Dry Weight}

Roots have a mechanism responsive to the soil environment [56], which has important effects on crop development and yield formation [57]. Our results suggested that the combination of different irrigation methods, deficit stages, and irrigation levels did not affect the general trend of the root dry weight, showing an inverted " $\mathrm{V}$ " trend, which was in good agreement with the result of Abrisqueta et al. [58]. Zhou et al. [59] found that the density of the grape root length under alternative drip irrigation was higher compared with that under conventional irrigation. Sampathkumar et al. [60] found that alternate drip irrigation with $100 \% \mathrm{ET}_{\mathrm{c}}$ engendered longer lateral roots and a greater root dry weight. However, our results suggested that there were large differences in the root dry weight of all treatments at harvest. In addition, CK obtained the greater root dry weight, and both those of $\mathrm{ASW}_{2}$ and $\mathrm{CSW}_{2}$ were the smallest. The possible reason for this is that the duration of the water deficit that occurred at $\mathrm{S}$ was too long and APRI lost its advantages. At the mature stage, the root dry weight in the $0 \sim 10 \mathrm{~cm}$ soil layer of the deficit at $S$ was greater than that at $\mathrm{M}$ under APRI. However, the root dry weight in the $10 \sim 50 \mathrm{~cm}$ layer under deficit irrigation at $\mathrm{S}$ was lower than that at $\mathrm{M}$, showing that rehydration can compensate for root growth. Furthermore, water stress led to root death.

\subsection{Yield Traits}

Qi et al. [61] revealed that irrigation and nitrogen application methods had an unremarkable impact on the cob length, cob diameter, and bald length of corn. Sarker et al. [61] found that the irrigation level and method had a significant impact on the crop water productivity and yield. In this study, we also found that the irrigation method had insignificant influences on the cob length and cob circumference, but there was an extremely significant influence of the irrigation method on the point length, grain number per cob, and grain yield. In the identical irrigation method, when water shortage occurred at $S$, the difference of the cob length and cob circumference between $W_{1}$ and $W_{2}$ was not significant. In comparison to $W_{2}$, the point length of $W_{1}$ was shorter, while the grain number per cob was higher. The grain yield of $W_{1}$ was significantly higher than that of $W_{2}$, which agreed with previous studies $[62,63]$.

Under the same irrigation method and irrigation level, the grain yield of water deficit at $\mathrm{S}$ was significantly higher than that at $\mathrm{M}$, which was due to the increase of the point length and the reduction of the grain number per cob. Our outcomes agreed with those reported by others $[25,64-66]$. Moreover, studies have indicated that a moderate water deficit before the jointing stage will not only lead to a reduction in the grain yield of maize $[65,67]$.

Some research has shown that there was no significant reduction in the grain yield when deficit occurred under APRI, compared with conventional deficit treatment $[30,68]$. Our results also found that the grain yield under APRI was higher than that under CI, but the difference between them was not significant, which agreed with Dodd et al. [69], Liu et al. [70], Kusakabe et al. [71], and Shu et al. [72]. Zhang et al. [73] found that APRI had an advantage in increasing the yield under deficit irrigation. This may be explained by the fact that the repeated cycles of alternating drying and rehydration caused by APRI induced root hair development after the soil had dried for some time [72]. Under different climatic conditions and durations and degrees of deficit, the signal transduction of plant hormones (including cytokinins) improved the nutritional status of crops, causing changes in both physical and biological aspects of crops, thus affecting the effectiveness of soil nutrients.

\subsection{Total Water Consumption and Water Use Efficiency}

A large number of studies have demonstrated that APRI can improve crops' WUE [16, 32,74-76]. In agreement with them, we also found that ET under CI was significantly higher than that under APRI at the same deficit stage and deficit level. Moreover, WUE, IWUE, WUE $\mathrm{B}_{\mathrm{B}}$ and $\mathrm{HI}$ under APRI were significantly higher than those under $\mathrm{CI}$ at the same deficit stage and irrigation level, which was in agreement with Liang et al. [31], 
who found that APRI increased WUE on the basis of the total dry mass. Although APRI and CI were applied for the same irrigation level at the same stage, their ET values were different. Compared with CI, APRI decreased the value by $14.64 \%$. Simultaneously, APRI increased the average WUE, IWUE, and $\mathrm{WUE}_{\mathrm{B}}$ by $30.37 \%, 20.40 \%$, and $27.42 \%$ compared to $C I$, respectively. Different degrees of water deficit at each growth stage of maize reduces the water consumption $[63,64,77,78]$. However, WUE and IWUE were enhanced by water deficit $[63,79,80]$. We also found that the ET of $W_{1}$ was significantly higher than that of $\mathrm{W}_{2}$ under the same irrigation method and deficit stage, but WUE and IWUE were not significantly different between these two irrigation levels. Although $\mathrm{W}_{2}$ reduced ET, it also caused a decrease in production. Under the same irrigation method and irrigation level, ET under water deficit at $\mathrm{M}$ was significantly greater than that at $\mathrm{S}$, but the WUE and IWUE of water deficit at $\mathrm{M}$ were significantly lower than those at $\mathrm{S}$.

\subsection{Multi-Objective Evaluation Based on the Entropy Weight and TOPSIS Methods}

The TOPSIS method has been widely used in project evaluations in the fields of land planning, water conservancy, power, engineering, and so on. Wang et al. [81] applied TOPSIS to optimize the management of water and fertilizer for high-yield and highquality potatoes. Rasool et al. [82] used TOPSIS to estimate the fruit quality index of tomatoes. Wang et al. [83] adopted TOPSIS to evaluate the irrigation and drainage patterns under different nitrogen levels in rice. However, in the process of TOPSIS calculation, an important step is determining the weight of each indicator [82]. Wang et al. [81] and Rasool et al. [82] both considered that the weights of the indicators were equal. In this study, the entropy weight method and the ideal point method were combined. The entropy weight is a typical diversity-based weighting method, which calculates attribute weights based on the diversity of attribute data (DAD) between schemes [34]. The weight of each index was determined by the entropy weight method, and the weight matrix was then constructed. According to the entropy weight and TOPSIS methods, the study found that multi-objective optimization was attained when $W_{1}$ occurred at $S$ under APRI.

\section{Conclusions}

Compared to CK, APRI and CI decreased ET by $34.7 \%$ and $23.8 \%$, respectively. In comparison to CK, APRI and CI increased WUE by $41 \%$ and $7.7 \%$, respectively. APRI increased IWUE and $\mathrm{WUE}_{\mathrm{B}}$ by $8.8 \%$ and $25.5 \%$, respectively. Additionally, because of the shorter tip length and larger grain number per cob, $\mathrm{ASW}_{1}$ obtained a similar grain yield to $\mathrm{CK}$ and the largest HI. However, compared to CK, CI and APRI significantly reduced the chlorophyll and carotenoid contents by $13.7 \%$ and $23.1 \%$ and $11.3 \%$ and $20.3 \%$, respectively. Deficit at the milking stage produced a longer tip length, causing a lower grain yield. When mild deficit irrigation (55 70\% FC) occurred at the seedling stage under APRI, multi-objective optimization was obtained.

Author Contributions: Conceptualization, J.F.; methodology, J.F.; software, H.W.; writing—original draft preparation, M.C.; writing-review and editing, H.W., J.F., and F.Z.; supervision, X.W.; funding acquisition, J.F. All authors have read and agreed to the published version of the manuscript.

Funding: This research was funded by [National Key Research and Development Program of China; National Natural Science Foundation of China; Youth Talent Cultivation Program of Northwest A\&F University; “111” Project] grant number [2016YFC0400201; 51879226; 2452020010; B12007].

Institutional Review Board Statement: Not appicable.

Informed Consent Statement: Not appicable.

Data Availability Statement: Data is contained within the article.

Conflicts of Interest: The authors declare no conflict of interest. 


\section{References}

1. Zhang, L.; Zhou, W.; Li, D. Research progress in irrigation mode selection of high-efficiency water-saving agriculture. J. Drain. Irrig. Mach. Eng. 2019, 37, 447-453. [CrossRef]

2. Yan, S.; Wu, Y.; Fan, J.; Zhang, F.; Qiang, S.; Zheng, J.; Xiang, Y.; Guo, J.; Zou, H. Effects of water and fertilizer management on grain filling characteristics, grain weight and productivity of drip-fertigated winter wheat. Agric. Water Manag. 2019, 213, 983-995. [CrossRef]

3. Wang, H.; Wu, L.; Cheng, M.; Fan, J.; Zhang, F.; Zou, Y.; Chau, H.W.; Gao, Z.; Wang, X. Coupling effects of water and fertilizer on grain yield, water and fertilizer use efficiency of drip-fertigated cotton in northern Xinjiang, China. Field Crops Res. 2018, 219, 169-179. [CrossRef]

4. Zheng, J.; Fan, J.; Zhang, F.; Yan, S.; Guo, J.; Chen, D.; Li, Z. Mulching mode and planting density affect canopy interception loss of rainfall and water use efficiency of dryland maize on the Loess Plateau of China. J. Arid Land. 2018, 10, 794-808. [CrossRef]

5. Albaji, M.; Golabi, M.; Nasab, S.B.; Zadeh, F.N. Investigation of surface, sprinkler and drip irrigation methods based on the parametric evaluation approach in Jaizan Plain. J. Saudi Soc. Agric. Sci. 2015, 14, 1-10. [CrossRef]

6. Kang, S.; Zhang, J.; Liang, Z.; Hu, X.; Cai, H. The controlled alternative irrigation-A new approach for water saving regulation in farm land. Agric. Res. Arid Areas 1997, 15, 1-6. (In Chinese) [CrossRef]

7. Huang, C.; Li, F.; Qin, Q.; Huang, C.; Luo, L.; Nong, M. Effect of partial root-zone irrigation on the growth and water use of sweet corn under two fertilization levels. Water Sav. Irrig. 2004, 6, 8-11. (In Chinese) [CrossRef]

8. Wang, C.; Shu, L.; Zhou, S.; Yu, H.; Zhu, P. Effects of alternate partial root-zone irrigation on the utilization and movement of nitrates in soil by tomato plants. Sci. Hortic. 2019, 243, 41-47. [CrossRef]

9. Abboud, S.; Dbara, S.; Abidi, W.; Braham, M. Differential agro-physiological responses induced by partial root-zone drying irrigation in olive cultivars grown in semi-arid conditions. Environ. Exp. Bot. 2019, 167, 103863. [CrossRef]

10. Elhani, S.; Haddadi, M.; Csákvári, E.; Zantar, S.; Hamim, A.; Villányi, V.; Douaik, A.; Bánfalvi, Z. Effects of partial root-zone drying and deficit irrigation on grain yield, irrigation water-use efficiency and some potato (Solanum tuberosum L.) quality traits under glasshouse conditions. Agric. Water Manag. 2019, 224, 105745. [CrossRef]

11. Du, T.; Kang, S.; Zhang, J.; Li, F. Grain yield and physiological responses of cotton to partial root-zone irrigation in the oasis field of northwest China. Agric. Water Manag. 2006, 84, 41-52. [CrossRef]

12. Du, S.; Kang, S.; Li, F.; Du, T. Water use efficiency is improved by alternate partial root-zone irrigation of apple in arid northwest China. Agric. Water Manag. 2017, 179, 184-192. [CrossRef]

13. Liang, J.; Li, F.; Tang, M.; Feng, Y. Effects of alternate partial root-zone irrigation on water and nitrogen utilization of pot-grown sweet corn. Trans. Chin. Soc. Agric. Eng. 2006, 22, 68-72. (In Chinese) [CrossRef]

14. Kang, S.; Liang, Z.; Pan, Y.; Shi, P.; Zhang, J. Alternate furrow irrigation for maize production in an arid area. Agric. Water Manag. 2000, 45, 267-274. [CrossRef]

15. Han, Y.; Kang, S. Effects of controlled root-divided alternative irrigation on nutrient uptake in maize. Irrig. Drain. 2001, 20, 5-7. (In Chinese) [CrossRef]

16. Li, P.; Qi, X.; Fan, X.; Wu, H.; Qiao, D.; Fan, T.; Zhao, Z.; Huang, Z.; Zhu, D. Effect of alternate partial root-zone irrigation on nitrogen and water use efficiency of potato. Trans. Chin. Soc. Agric. Eng. 2009, 25, 92-95. (In Chinese)

17. Wang, D.; Zhou, Y.; Lu, Z.; Xiao, M.; Xu, W.; Huang, R. Root morphology and activity of stay green maize under water stress. J. Maize Sci. 2012, 20, 84-87. (In Chinese)

18. Yuan, C.; Feng, S.; Huo, Z.; Wang, Q. Simulation of deficit irrigation with saline water for spring maize based on SWAP model. J. Drain. Irrig. Mach. Eng. 2020, 38, 396-402. [CrossRef]

19. Lv, Z.; Zhang, L.; Li, Y.; Wang, H. Effects of water deficit on physiological indexes and grain yield of maize. Water Sav. Irrig 2011, 7, 11-12. (In Chinese)

20. Comas, L.; Trout, T.; DeJonge, K.; Zhang, H.; Gleason, S. Water productivity under strategic growth stage-based deficit irrigation in maize. Agric. Water Manag. 2019, 212, 433-440. [CrossRef]

21. Wang, M.; Kang, S.; Cai, H.; Ma, X. Study on the mechanism of saving water of regulated deficit irrigation in maize. J. Northwest Sci-Tech Univ. Agric. For. 2004, 32, 87-90. (In Chinese) [CrossRef]

22. Kirda, C.; Topcu, S.; Kaman, H.; Ulger, A.C.; Yazici, A.; Cetin, M.; Derici, R. Grain yield response and N-fertilizer recovery of maize under deficit irrigation. Field Crops Res. 2005, 93, 132-141. [CrossRef]

23. Geerts, S.; Raes, D. Deficit irrigation as an on-farm strategy to maximize crop water productivity in dry areas. Agric. Water Manag. 2009, 96, 1275-1284. [CrossRef]

24. Li, X.; Kang, S.; Zhang, X.; Li, F.; Lu, H. Deficit irrigation provokes more pronounced responses of maize photosynthesis and water productivity to elevated $\mathrm{CO}_{2}$. Agric. Water Manag. 2018, 195, 71-83. [CrossRef]

25. Kebede, H.; Sui, R.; Fisher, D.K.; Reddy, K.N.; Bellaloui, N.; Molin, W.T. Corn yield response to reduced water use at different growth stages. Agric. Sci. 2014, 5, 1305-1315. [CrossRef]

26. Kang, S.; Shi, W.; Hu, X.; Liang, Y. Effect of regulated deficit irrigation on physiological indexes and water use efficiency of maize. Trans. Chin. Soc. Agric. Eng. 1998, 14, 82-87. (In Chinese)

27. Wei, Y.; Ma, Y.; Liu, H.; Zhang, Y.; Yang, J.; Zhang, Y. Effects of soil water, plant, water saving and grain yield increasing of maize under regulated deficit drip irrigation. Trans. Chin. Soc. Agric. Mach. 2018, 49, 252-260. (In Chinese) [CrossRef] 
28. Liu, Y.; Li, F.; Nong, M. Effects of alternate partial root-zone irrigation on water saving and quality regulating of flue-cured tobacco at different growth stages. Trans. Chin. Soc. Agric. Eng. 2009, 25, 16-20. (In Chinese)

29. Wang, L.; Shi, H.; Wu, J.; Cao, F. Alternative partial root-zone irrigation enhances leaf flavonoid accumulation and water use efficiency of ginkgo biloba. New For. 2016, 47, 377-391. [CrossRef]

30. Karandish, F.; Shahnazari, A. Soil temperature and maize nitrogen uptake improvement under partial root-zone drying irrigation. Pedosphere 2016, 26, 872-886. [CrossRef]

31. Liang, H.; Li, F.; Nong, M. Effects of alternate partial root-zone irrigation on yield and water use of sticky maize with fertigation. Agric. Water Manag. 2013, 116, 242-247. [CrossRef]

32. Liu, X.; Zhang, F.; Yang, Q.; Tian, Y. Effects of controlled root-divided irrigation on transport and utilization of water and nitrogen in maize root-zone soil. Trans. Chin. Soc. Agric. Eng. 2009, 25, 61-67. (In Chinese) [CrossRef]

33. Hwang, C.L.; Yoon, K.P. Multiple Attribute Decision Making: Methods and Applications; Springer: New York, NY, USA, 1981.

34. Chen, P.Y. Effects of the entropy weight on TOPSIS. Expert Syst. Appl. 2020, 114186. [CrossRef]

35. Chen, P.Y. On the diversity-based weighting method for risk assessment and decision-making about natural hazar. Entropy 2019, 21, 269. [CrossRef] [PubMed]

36. Du, T.; Kang, S.; Zhang, J.; Li, F.; Hu, X. Water use and grain yield responses of cotton to alternate partial root-zone drip irrigation in the arid area of northwest China. Irrig. Sci. 2008, 26, 147-159. [CrossRef]

37. Fan, J.; Wu, L.; Zhang, F.; Xiang, Y.; Zheng, J. Climate change effects on reference crop evapotranspiration across different climatic zones of China during 1956-2015. J. Hydrol. 2016, 542, 923-937. [CrossRef]

38. Montgomery, E. Correlation studies in corn. Nebraska agricultural experiment station. Annu. Rep. 1911, 24, 108-159.

39. Xie, G.; Han, D.; Wang, X.; Lv, R. Harvest index and residue factor of non-cereal crops in China. J. China Agric. Univ. 2011, 16, 1-8. (In Chinese)

40. Ierna, A.; Pandino, G.; Lombardo, S.; Mauromicale, G. Tuber grain yield, water and fertilizer productivity in early potato as affected by a combination of irrigation and fertilization. Agric. Water Manag. 2011, 101, 35-41. [CrossRef]

41. Zou, Q. Guide of Phytophysiological Experiment; China Agriculture Press: Beijing, China, 1995. (In Chinese)

42. Wang, J.; Kang, S.; Zhang, F.; Li, Z. Effects of controlled alternate partial rootzone irrigation on soil microorganism and growth of maize. Sci. Agric. Sin. 2006, 39, 2056-2062. (In Chinese) [CrossRef]

43. Li, F.; Liang, J.; Kang, S.; Zhang, J. Benefits of alternate partial root-zone irrigation on growth, water and nitrogen use efficiencies modified by fertilization and soil water status in maize. Plant Soil 2007, 295, 279-291. [CrossRef]

44. Song, F.; Dai, J. Response and adaptability of the growth of leaves, stems and roots of maize to drought stress. Arid Zone Res. 2005, 22, 256-258. (In Chinese)

45. Wang, Y.; Janz, B.; Engedal, T.; Neergaard, A. Effect of irrigation regimes and nitrogen rates on water use efficiency and nitrogen uptake in maize. Agric. Water Manag. 2016, 179, 271-276. [CrossRef]

46. Guo, Z.; Gong, D.; Hao, W.; Mei, X.; Li, Y.; Liu, B. Study on compensation of maize varieties under drought stress and re-watering in different growth stages. J. Maize Sci. 2011, 19, 84-88. (In Chinese) [CrossRef]

47. Yan, Y.; Luo, X.; Zhang, X.; Lan, W. Comparison of maize physiological characters under different treatment of irrigation. Chin. Agric. Sci. Bull. 2007, 23, 323-326. (In Chinese) [CrossRef]

48. Wei, C.; Li, F.; Xu, C.; Nong, M.; Yu, J.; Luo, H. Effect of regulated deficit irrigation and fertilization on dry matter accumulation and related physiological properties of maize. Agric. Res. Arid Areas 2010, 28, 76-84. (In Chinese)

49. Xing, Y.; Zhang, F.; Wang, X. Effects of water deficit irrigation at different growth stages and nitrogen nutrition on the growth of maize. Agric. Res. Arid Areas 2010, 28, 1-11. (In Chinese)

50. Zhang, Z.; Cai, H. Influences of water deficit on growth, development and grain yield in plastic-mulched spring maize. J. Irrig. Drain. 2011, 20, 13-16. (In Chinese) [CrossRef]

51. Zhang, R.; Cheng, Z.; Li, Y. Effect of regulated deficit drip irrigation on growth characteristic and grain yield of plastic-filmmulched corn for seed. Agric. Res. Arid Areas 2009, 27, 125-128. (In Chinese)

52. Yang, D.; Shen, X.; Zhao, T.; Ma, X. Achievement of drought-injury physiology in maize. Crops 2001, 5, 1-4. (In Chinese) [CrossRef]

53. Li, F.; Wei, C.; Zhang, F.; Zhang, J.; Nong, M.; Kang, S. Water-use efficiency and physiological responses of maize under partial root-zone irrigation. Agric. Water Manag. 2010, 97, 1156-1164. [CrossRef]

54. Lu, W.; Li, F.; Nong, M. Effects of alternate partial root-zone irrigation on physiological characteristics and water use of maize under different water and fertilizer conditions. Acta Ecol. Sin. 2014, 34, 5257-5265. (In Chinese) [CrossRef]

55. Fu, F.; Lu, W.; Li, F. Effects of partial root-zone irrigation at different water-control duration on physiology and water use efficiency of maize. J. Plant Nutr. Fertil. 2014, 20, 1378-1386. (In Chinese) [CrossRef]

56. Norwood, M. Investigation into the ability of roots of the poikilohydric plant Craterostigma plantagineum to survive dehydration stress. J. Exp. Bot. 2003, 54, 2313-2321. [CrossRef] [PubMed]

57. Grant, R.F. Simulation in ecosystem of root growth response to contrasting soil water and nitrogen. Ecol. Model. 1998, 107, 237-264. [CrossRef]

58. Abrisqueta, J.M.; Mounzer, O.; álvarez, S.; Conejero, W.; García-Orellana, Y.; Tapia, L.M.; Vera, J.; Abrisqueta, I.; Ruiz-Sánchez, M.C. Root dynamics of peach trees submitted to partial rootzone drying and continuous deficit irrigation. Agric. Water Manag. 2008, 95, 959-967. [CrossRef] 
59. Zhou, Q.; Wang, Y.; Sun, S. Distribution characteristic and growing dynamic of grape vine roots under alternate partial root zone drip irrigation. Trans. Chin. Soc. Agric. Mach. 2011, 42, 58-63. [CrossRef]

60. Sampathkumar, T.; Pandian, B.J.; Mahimairaja, S. Soil moisture distribution and root characters as influenced by deficit irrigation through drip system in cotton-maize cropping sequence. Agric. Water Manag. 2012, 103, 43-53. [CrossRef]

61. Qi, W.; Li, E.; Zhai, H.; Wang, X.; Du, Y. Physiological and biochemical responses of different scion/rootstock combinations grapevine to partial root-zone drought. Chin. J. Appl. Ecol. 2008, 19, 306-310. (In Chinese) [CrossRef]

62. Sarker, K.K.; Hossain, A.; Timsina, J.; Biswas, S.K.; Malone, S.L.; Alam, M.K.; Loescher, H.W.; Bazzaz, M. Alternate furrow irrigation can maintain grain yield and nutrient content, and increase crop water productivity in dry season maize in sub-tropical climate of South Asia. Agric. Water Manag. 2020, 238, 106229. [CrossRef]

63. Yilmaz, E.; Akcay, S.; Gürbüz, T.; Dağdelen, N.; Sezgin, F. Effect of different water stress on the yield and yield components of second crop corn in semiarid climate. J. Food Agric. Environ. 2010, 8, 415-421. [CrossRef]

64. Qiu, X.; Lu, Z.; Zhang, Y.; Meng, C.; Liu, Z.; Liu, Z.; Xiao, J. Effects of drought in different growth stages on water consumption and water use efficiency of summer maize. Chin. Agric. Sci. Bull. 2013, 27, 68-75. (In Chinese) [CrossRef]

65. Çakir, R. Effect of water stress at different development stages on vegetative and reproductive growth of corn. Field Crops Res. 2004, 89, 1-16. [CrossRef]

66. Zhang, Z.; Liu, H.; Zhang, L.; Liu, Y.; Ding, M.; Zhu, M. Responses of physiological and growth traits and the grain yield of maize to water deficit occurring at different growth stages. J. Irrig. Drain. 2018, 37, 9-17. (In Chinese) [CrossRef]

67. Wang, Y.; Tao, H.; Zhao, L.; Zhao, X.; Jin, P.; Wang, C.; Wang, P. Response of maize to water deficit. J. Maize Sci. 2014, 22, 87-92. (In Chinese)

68. Tang, L.; Li, Y.; Zhang, J. Partial rootzone irrigation increases water use efficiency, maintains yield and enhances economic profit of cotton in arid area. Agric. Water Manag. 2010, 97, 1527-1533. [CrossRef]

69. Dodd, I.C.; Puértolas, J.; Huber, K.; Pérez-Pérez, J.G.; Wright, H.R.; Blackwell, M.S.A. The importance of soil drying and re-wetting in crop phytohormonal and nutritional responses to deficit irrigation. J. Exp. Bot. 2015, 66, 2239-2252. [CrossRef]

70. Liu, R.; Yang, Y.; Wang, Y.; Wang, X.; Rengel, Z.; Zhang, W.; Shu, L. Alternate partial root-zone drip irrigation with nitrogen fertigation promoted tomato growth, water and fertilizer-nitrogen use efficiency. Agric. Water Manag. 2020, 233, 106049. [CrossRef]

71. Kusakabe., A.; Contreras-Barragan, B.A.; Simpson, C.R.; Enciso, J.M.; Nelson, S.D.; Melgar, J.C. Application of partial rootzone drying to improve irrigation water use efficiency in grapefruit trees. Agric. Water Manag. 2016, 178, 66-75. [CrossRef]

72. Shu, L.; Liu, R.; Min, W.E.I.; Wang, Y.; Yu, H.; Zhu, P.; Zhu, J. Regulation of soil water threshold on tomato plant growth and fruit quality under alternate partial root-zone drip irrigation. Agric. Water Manag. 2020, 238. [CrossRef]

73. Zhang, Q.; Wu, S.; Chen, C.; Shu, L.; Zhou, X.; Zhu, S. Regulation of nitrogen forms on growth of eggplant under partial root-zone irrigation. Agric. water Manag. 2014, 142, 56-65. [CrossRef]

74. Topak, R.; Acar, B.; Uyanoz, R.; Ceyhan, E. Performance of partial root-zone drip irrigation for sugar beet production in a semi-arid area. Agric. Water Manag. 2016, 176, 180-190. [CrossRef]

75. Wei, Z.; Du, T.; Zhang, J.; Xu, S.; Cambre, P.J.; Dacies, W.J. Carbon isotope discrimination shows a higher water use efficiency under alternate partial root-zone irrigation of field-grown tomato. Agric. Water Manag. 2016, 165, 33-43. [CrossRef]

76. Sarker, K.K.; Hossain, A.; Timsina, J.; Biswas, S.K.; Kundu, B.C.; Barman, A.; Murad, K.F.L.; Akter, F. Grain yield and quality of potato tuber and its water productivity are influenced by alternate furrow irrigation in a raised bed system. Agric. Water Manag. 2019, 224, 105750. [CrossRef]

77. Xiao, J.; Liu, Z.; Liu, Z.; Nan, J. Effects of drought at different growth stages and different water availabilities on growth and water consumption characteristics of summer maize. J. Maize Sci. 2011, 19, 54-58. (In Chinese)

78. Wang, X.; Wang, G.; Guo, T.; Xing, Y.; Mo, F.; Wang, H.; Fan, J.; Zhang, F. Effects of plastic mulch and nitrogen fertilizer on the soil microbial community, enzymatic activity and yield performance in a dryland maize cropping system. Eur. J. Soil Sci. 2020, 1-13. [CrossRef]

79. Igbadun, H.E.; Salim, B.A.; Tarimo, A.K.P.R.; Mahoo, H.F. Effects of deficit irrigation scheduling on grain yields and soil water balance of irrigated maize. Irrig. Sci. 2008, 27, 11-23. [CrossRef]

80. Mansouri-Far, C.; Sanavy, S.A.M.M.; Saberali, S.F. Maize grain yield response to deficit irrigation during low-sensitive growth stages and nitrogen rate under semi-arid climatic conditions. Agric. Water Manag. 2010, 97, 12-22. [CrossRef]

81. Wang, H.; Wang, X.; Bi, L.; Wang, Y.; Fan, J.; Zhang, F.; Hou, X.; Cheng, M.; Hu, W.; Wu, L.; et al. Multi-objective optimization of water and fertilizer management for potato production in sandy areas of northern China based on TOPSIS. Field Crops Res. 2019, 240, 55-68. [CrossRef]

82. Rasool, G.; Guo, X.; Wang, Z.; Ali, M.U.; Ullah, M.S. Coupling fertigation and buried straw layer improves fertilizer use efficiency, fruit yield, and quality of greenhouse tomato. Agric. Water Manag. 2020, 239, 106239. [CrossRef]

83. Wang, Y.; Yu, S.; Ding, J.; Li, Q.; Zhang, M.; Liu, Z.; Chen, K. Entropy weight TOPSIS model-based evaluation of rice irrigation and drainage modes at different nitrogen application levels. J. Drain. Irrig. Mach. Eng. 2020, 38, 720-725. [CrossRef] 